\title{
Plexina2 and CRMP2 Signaling Complex Is Activated by Nogo-A-Liganded Ngr1 to Restrict Corticospinal Axon Sprouting after Trauma
}

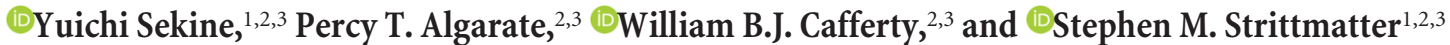 \\ ${ }^{1}$ Cellular Neuroscience, Neurodegeneration, and Repair Program, Yale University School of Medicine, New Haven, Connecticut 06536, ${ }^{2}$ Departments of \\ Neurology, and ${ }^{3}$ Neuroscience, Yale University School of Medicine, New Haven, Connecticut 06520
}

After brain or spinal cord trauma, interaction of Nogo-A with neuronal NgR1 limits regenerative axonal sprouting and functional recovery. Cellular signaling by lipid-anchored NgR1 requires a coreceptor but the relevant partner in vivo is not clear. Here, we examined proteins enriched in NgR1 immunoprecipitates by Nogo-A exposure, identifying CRMP2, a cytosolic protein implicated in axon growth inhibition by Semaphorin/Plexin complexes. The Nogo-A-induced association of NgR1 with CRMP2 requires PlexinA2 as a coreceptor. Non-neuronal cells expressing both NgR1 and PlexinA2, but not either protein alone, contract upon Nogo-A exposure. Inhibition of cortical axon regeneration by Nogo-A depends on a NgR1/PlexinA2 genetic interaction because double-heterozygous $\mathrm{NgR} 1^{+/-}$, PlexinA2 ${ }^{+/-}$neurons, but not single-heterozygote neurons, are rescued from Nogo-A inhibition. NgR1 and PlexinA2 also interact genetically in vivo to restrict corticospinal sprouting in mouse cervical spinal cord after unilateral pyramidotomy. Greater post-injury sprouting in $\mathrm{NgR} 1^{+/-}$, PlexinA2 ${ }^{+/-}$mice supports enhanced neurological recovery of a mixed female and male double-heterozygous cohort. Thus, a NgR1/PlexinA2/CRMP2 ternary complex limits neural repair after adult mammalian CNS trauma.

Key words: corticospinal; CRMP; Nogo receptor; plasticity; Plexin; pyramidotomy

\section{Significance Statement}

Several decades of molecular research have suggested that developmental regulation of axon growth is distinct in most regards from titration of axonal regenerative growth after adult CNS trauma. Among adult CNS pathways, the oligodendrocyte Nogo-A inhibition of growth through $\mathrm{NgR} 1$ is thought to have little molecular relationship to axonal guidance mechanisms active embryonically. Here, biochemical analysis of NgR1 function uncovered a physical complex with CRMP cytoplasmic mediators, and this led to appreciation of a role for PlexinA2 in concert with NgR1 after adult trauma. The data extend molecular understanding of neural repair after CNS trauma and link it to developmental processes.

\section{Introduction}

During nervous system development, connectivity is sculpted by repulsion of axons from inappropriate paths or territories (Tessier-Lavigne and Goodman, 1996). Semaphorin, Ephrin, Slit, and Netrin ligands play inhibitory roles for particular neurons at particular locations. In the mature mammalian CNS,

\footnotetext{
Received Nov. 27, 2018; revised Jan. 31, 2019; accepted Feb. 17, 2019.

Author contributions: Y.S., W.B.J.C., and S.M.S. designed research; Y.S., P.T.A., and W.B.J.C. performed research; Y.S. and S.M.S. analyzed data; Y.S. and S.M.S. wrote the first draft of the paper; Y.S., P.T.A., W.B.J.C., and S.M.S. edited the paper; Y.S. and S.M.S. wrote the paper.

This work was supported by Grants from the Falk Medical Research Trust and the NIH to S.M.S.

S.M.S. is a co-founder, shareholder, and consultant for ReNetX Bio, which seeks to develop NgR1-based therapies

for neural repair. The remaining authors declare no competing financial interests.

Correspondence should be addressed to Stephen M. Strittmatter at stephen.strittmatter@yale.edu.

https://doi.org/10.1523/JNEUROSCI.2996-18.2019

Copyright $\odot 2019$ the authors
}

trauma of the spinal cord or brain results in persistent neurological deficits in large part because of the severing of axons in the neural network. The regenerative growth of axons is strongly inhibited by the adult mammalian CNS environment, as well as by cell-autonomous factors (Liu et al., 2006, 2011; Dell'Anno and Strittmatter, 2017). These facts highlight the issue of whether development axon repulsion shares mechanisms with inhibition of adult reparative axonal growth.

Molecular investigations of molecules implicated in developmental axonal repulsion and extrinsic limitation of adult reparative axon growth have suggested little overlap. In general, ligand and receptor expression shifts substantially as the nervous system matures and does not shift back after adult CNS injury (Harel and Strittmatter, 2006). The extrinsic inhibitory factors unique to the adult CNS are derived to a major extent from glia and include components of myelin-forming oligodendrocytes and astrocytic 
scars (Liu et al., 2006). Chondroitin sulfate proteoglycans are prominent among astrocytic inhibitors (Snow et al., 1990; Bradbury et al., 2002; Fawcett, 2015) and oligodendrocyte inhibitors of axonal growth include Nogo-A (RTN4A), MAG, and OMgp (McKerracher et al., 1994; Mukhopadhyay et al., 1994; Chen et al., 2000; GrandPré et al., 2000; Kottis et al., 2002). All three of these oligodendrocyte ligands bind to NgR1 (RTN4R; Fournier et al., 2001; Liu et al., 2002; Wang et al., 2002b; Laurén et al., 2007) and to PirB (LiLRB2; Atwal et al., 2008; Huebner et al., 2011). Genetic and pharmacological studies document that NgR1 has a role in limiting axonal regeneration, sprouting and plasticity after adult CNS trauma (GrandPré et al., 2002; Kim et al., 2004; Lee et al., 2004; Li et al., 2004; McGee et al., 2005; Cafferty and Strittmatter, 2006; Wang et al., 2006, 2011, 2014; Akbik et al., 2013; Fink et al., 2015; Bhagat et al., 2016).

Although NgR1 participates in limiting axonal growth in the adult mammalian CNS, its mechanism of signaling is less clear. The protein is GPI-anchored at the neuronal surface, implying the existence of transmembrane coreceptor(s) to initiate signal transduction (Fournier et al., 2001). A downstream effector of Nogo-A-NgR1 signaling is RhoA (Jin and Strittmatter, 1997; Fournier et al., 2003; Duffy et al., 2009), but the transmembrane coupling mechanism to this cytoplasmic mediator is incompletely understood. In certain cell systems, p75NTR and/or the related protein TROY, together with Lingo-1 play a role (Wang et al., 2002a; Mi et al., 2004; Park et al., 2005; Shao et al., 2005). However, Lingo-1's primary function may be in oligodendrocytes rather than neurons, and in vivo studies of these proteins have demonstrated limited effects on axonal growth after trauma (Song et al., 2004; Mi et al., 2005, 2007; Ji et al., 2006).

Here, we sought to explore NgR1 signal transduction, reasoning that association with relevant molecules in neurons would be regulated by ligand. Analysis of Nogo-A-induced protein partners of NgR1 revealed CRMP2 protein. Because CRMP proteins mediate Semaphorin signaling by Plexin-containing receptors (Goshima et al., 1995; Deo et al., 2004; Schmidt and Strittmatter, 2007; Schmidt et al., 2008), we explored a role for Plexins in linking NgR1 to intracellular transduction. Coexpression of PlexinA2 links NgR1 to CRMP2 and to non-neuronal cell contraction. Cortical neurons lacking PlexinA2 do not respond to Nogo-A ligand. Although deletion of one allele of NgR1 or PlexinA2 does not alter in vitro regulation of axon regeneration by Nogo-A or recovery from corticospinal lesions in vivo, the double-heterozygous state recapitulates the null phenotype with greater axonal growth and recovery. Thus, biochemical studies demonstrate a ternary NgR1/PlexinA2/CRMP2 complex in which NgR1 and PlexinA2 interact genetically to mediate axonal growth inhibition.

\section{Materials and Methods}

Antibody use. The following antibodies were used with indicated dilutions: mouse monoclonal antibodies to $\beta$ III-Tubulin (1:2000 ICC; Promega), $\beta$-Actin (1:3000 IB), c-Myc (1:2000 IB), HA (1:2000 IB, 1:1000 ICC), VSV (1:2000 IB; Sigma-Aldrich), CRMP2 (1:2000 IB; ImmunoBiological Laboratories), CRMP4 (1:2000 IB), Jup (1:2000 IB), and PlexinA2 (1:1000 IB; Santa Cruz Biotechnology): rabbit monoclonal antibody to Myosin IIb (1:1000 IB; Cell signaling Technology): rabbit polyclonal antibodies to FLAG (1:2500 IB; Sigma-Aldrich) and PKC $\gamma(1$ : 1000 IHC; Santa Cruz Biotechnology): goat polyclonal anti-NgR1 antibody (1:2000 IB, 1:1000 ICC; R\&D Systems). The following secondary antibodies were used: donkey antibodies to mouse IgG AlexaFluor 488, 568, 647, rabbit IgG AlexaFluor 568 (1:1000 ICC, IHC; ThermoFisher Scientific), mouse IgG $(\mathrm{H}+\mathrm{L})$ IRDye 680, rabbit IgG $(\mathrm{H}+\mathrm{L})$ IRDye 680, 800, and goat IgG (H+L) IRDye 800 (1:10,000 IB; Li-Cor).
Table 1. Summary of statistical analyses for Figures $7 E, F$ and $8 A, B$

\begin{tabular}{|c|c|c|}
\hline & Summary & $p$ \\
\hline \multicolumn{3}{|l|}{ Tukey's multiple-comparisons test } \\
\hline \multicolumn{3}{|l|}{ Fig. $7 E$} \\
\hline WT vs NgR ${ }^{+/-}$ & ns & 0.360 \\
\hline WT vs PlexA2 ${ }^{+/-}$ & ns & 0.395 \\
\hline WT vs NgR ${ }^{+/-}$Plex ${ }^{+/-}$ & $*$ & 0.019 \\
\hline $\mathrm{NgR}^{+/-}$vs PlexA2 $2^{+/-}$ & ns & $>0.999$ \\
\hline $\mathrm{NgR}^{+/-}$vs NgR $^{+/-} \mathrm{Plex}^{+/-}$ & ns & 0.442 \\
\hline $\mathrm{PlexA2}^{+/-} \mathrm{vs} \mathrm{NgR}^{+/-} \mathrm{Plex}^{+/-}$ & ns & 0.466 \\
\hline \multicolumn{3}{|l|}{ Fig. $7 F$} \\
\hline WT vs NgR ${ }^{+/-}$ & ns & 0.100 \\
\hline WT vs PlexA2 $2^{+1-}$ & ns & 0.441 \\
\hline WT vs $\mathrm{NgR}^{+/-}$Plex ${ }^{+/-}$ & $*$ & 0.023 \\
\hline $\mathrm{NgR}^{+/-}$vs PlexA2 $^{+/-}$ & ns & 0.864 \\
\hline $\mathrm{NgR}^{+/-}$vs NgR $^{+/-} \mathrm{Plex}^{+/-}$ & ns & 0.880 \\
\hline $\mathrm{PlexA2}^{+/-} \mathrm{vs} \mathrm{NgR}^{+/-} \mathrm{Plex}^{+/-}$ & ns & 0.468 \\
\hline \multicolumn{3}{|l|}{ Fig. $8 A$, Day 28} \\
\hline WT vs $\mathrm{NgR}^{+/-}$ & ns & 0.272 \\
\hline WT vs PlexA2 ${ }^{+/-}$ & ns & 0.256 \\
\hline WT vs $\mathrm{NgR}^{+/-}$Plex ${ }^{+/-}$ & $* *$ & 0.003 \\
\hline $\mathrm{NgR}^{+/-}$vs PlexA2 $2^{+/-}$ & ns & 1.000 \\
\hline $\mathrm{NgR}^{+/-}$vs NgR $^{+/-} \mathrm{Plex}^{+/-}$ & ns & 0.174 \\
\hline PlexA2 $^{+/-} \mathrm{vs} \mathrm{NgR}^{+/-} \mathrm{Plex}^{+/-}$ & ns & 0.232 \\
\hline \multicolumn{3}{|l|}{ Parametric paired $t$ test } \\
\hline \multicolumn{3}{|l|}{ Fig. $8 B$} \\
\hline WT, Day 2 vs Day 28 & ns & 0.1844 \\
\hline $\mathrm{NgR}^{+/-}$, Day 2 vs Day 28 & $*$ & 0.0165 \\
\hline PlexA2 ${ }^{+1-}$, Day 2 vs Day 28 & $*$ & 0.0477 \\
\hline $\mathrm{NgR}^{+/-}$Plex $^{+/-}$, Day 2 vs Day 28 & $* * *$ & 0.0004 \\
\hline \multicolumn{3}{|l|}{ Bonferroni correction } \\
\hline \multicolumn{3}{|l|}{ Fig. $8 B$} \\
\hline WT, Day 2 vs Day 28 & ns & 0.7376 \\
\hline $\mathrm{NgR}^{+/-}$, Day 2 vs Day 28 & ns & 0.066 \\
\hline PlexA2 ${ }^{+\prime-}$, Day 2 vs Day 28 & ns & 0.1908 \\
\hline $\mathrm{NgR}^{+/-}$Plex ${ }^{+/-}$, Day 2 vs Day 28 & $* *$ & 0.0016 \\
\hline
\end{tabular}

Expression plasmids. FLAG-NgR1(Sekine et al., 2018a), Nogo22 (Huebner et al., 2011), PlexinA1-Myc (Takahashi et al., 1999), PlexinA4Myc (Suto et al., 2003), HA-neuropilin (Nakamura et al., 1998), APNogo66 (Laurén et al., 2007), p75, and Lingo (Budel et al., 2008) have been previously described. VSV-PlexinA3 was a gift from Dr. Andreas Puschel, University of Munster. Human PlexinA2 (Takahashi and Strittmatter, 2001) was used for generating C-terminal HA-tagged WT (11894 aa) and delta-cyto (1-1274 aa) constructs by PCR methods and subcloned into pcDNA3.1 TOPO vector. Myc-DDK-tagged human CRMP2 construct (catalog \#RC209080) was obtained from OriGene.

Cell culture and transfection. Human embryonic kidney 293T (HEK293T) and African green monkey kidney Cos7 were maintained in DMEM containing $10 \%$ FCS, $100 \mathrm{U} / \mathrm{ml}$ penicillin and $100 \mu \mathrm{g} / \mathrm{ml}$ streptomycin. Plasmids were transfected with Lipofectamine 2000 (Invitrogen) following the manufacturer's instruction.

Immunoprecipitation, silver staining, and mass spectrometry. Twentyone day in vitro (DIV) neurons or transfected HEK293T cells were lysed with a RIPA buffer (50 mм Tris- $\mathrm{HCl}$, pH7.4, 150 mм NaCl, 1 mм EDTA, $0.1 \%$ SDS, $0.5 \%$ sodium deoxycholate, and $1 \%$ Triton X-100) and centrifuged at $20,000 \times g$ for $20 \mathrm{~min}$ at $4^{\circ} \mathrm{C}$. The supernatants were added with the antibody and protein G-Sepharose mixture and incubated for $2 \mathrm{~h}$ at $4^{\circ} \mathrm{C}$ with gentle rotation. The beads were washed three times and the immune complexes were then resolved by SDS-PAGE. For mass spectrometry, the gel was stained by Silver Stain MS kit (Wako, 299-58901) according to the manufacturer's instructions, and the bands were excised and subjected to analysis by mass spectrometry (the MS and Proteomics Resource of the WM Keck Foundation Biotechnology Resource Laboratory at Yale University).

Immunoblotting. Cell lysate or immunoprecipitated samples were resolved by SDS-PAGE and transferred to nitrocellulose membranes. 


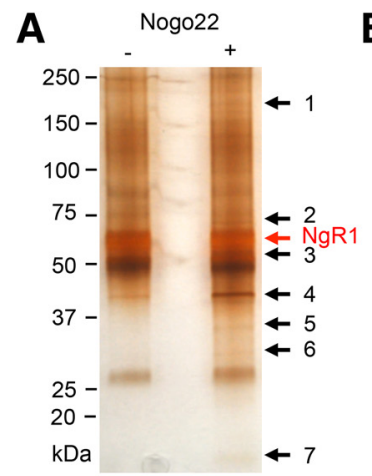

\begin{tabular}{|c|c|c|c|c|c|c|}
\hline Band \# & Score & Expectation & GenBank ID & Official Symbol & MW & \%Coverage \\
\hline 1 & 82 & 0.00099 & BAC65860 & Myh10 & 212352 & 1.1 \\
\hline 2 & 606 & $3.70 E-56$ & AAB02885 & Jup & 68068 & 24.3 \\
\hline 2 & 267 & $2.80 E-22$ & AAA37869 & Hspa8 & 70793 & 17.2 \\
\hline 3 & 248 & $2.20 E-20$ & NP_033494 & Dpysl3(CRMP4) & 61897 & 12.3 \\
\hline 3 & 130 & $1.40 E-08$ & CAA71370 & DpysI2(CRMP2) & 62132 & 11.9 \\
\hline 4 & 803 & $7.80 E-76$ & CAA27396 & Actb & 39161 & 59.6 \\
\hline 5 & 117 & $2.70 E-07$ & NP_032110 & Gapdh & 35787 & 17.1 \\
\hline 6 & 80 & 0.0015 & CAA27397 & Acta1 & 37788 & 4.8 \\
\hline 6 & 59 & 0.17 & AAC72250 & Gnb2 & 37309 & 6.2 \\
\hline 7 & 251 & $1.00 E-20$ & NP 031713 & Cfl1 & 18548 & 45.8 \\
\hline
\end{tabular}
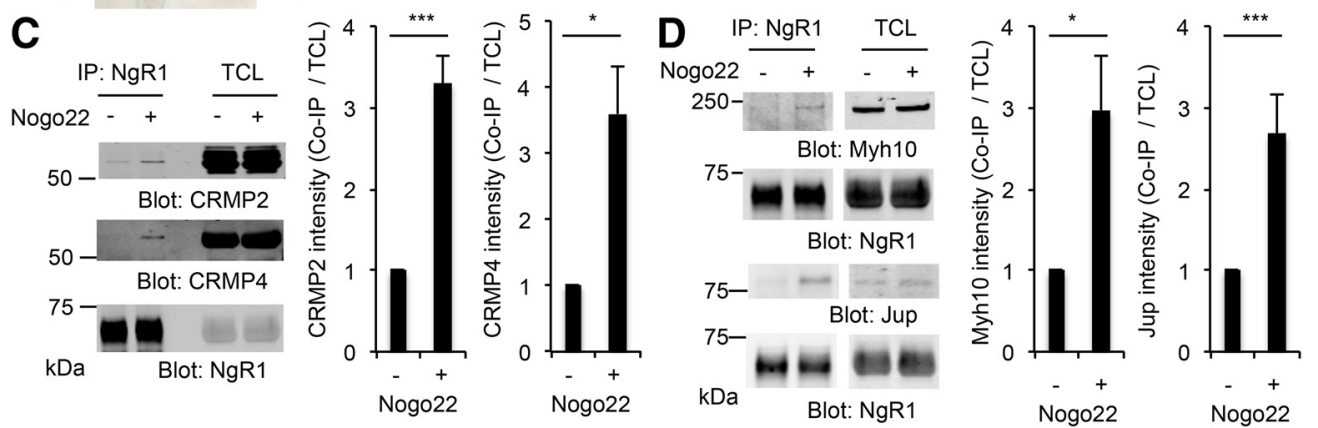

Figure 1. Identification of NgR1 interacting proteins by Nogo-A stimulation. $A$, Twenty-one DIV cortical neurons were stimulated without or with Nogo22 (100 nм) for 5 min and then the lysate was immunoprecipitated with anti-NgR1 antibody. The immunoprecipitates were resolved by SDS-PAGE and visualized by silver staining. Black arrow bands were excised and analyzed by LC/MS to determine their identity. Red arrow shows immunoprecipitated NgR1 protein band. B, List of proteins determined their identity by LC/MS. C, D, NgR1 immunoprecipitates from 21 DIV cortical neurons stimulated without or with Nogo22 (100 nM) for 5 min were resolved by SDS-PAGE and immunoblotted for CRMP2, (RMP4 (C), and Myh10, Jup, and NgR1 (D). The graphs show the quantification of each protein levels in the immunoprecipitates normalized to total cell lysate from CRMP2 $(n=3)$, CRMP4 $(n=3), \operatorname{Myh} 10(n=4)$, and Jup $(n=4)$. Mean \pm SE. ${ }^{*} p<0.05$, ${ }^{* * *} p<$ 0.005 , Student's two-tailed $t$ test.

Then, they were incubated in blocking buffer (Blocking Buffer for Fluorescent Western Blotting, Rockland MB-070-010) for $1 \mathrm{~h}$ at RT and immunoblotted with the appropriate primary antibodies. Following primary antibody incubation, secondary antibodies (Odyssey IRDye 680 or 800) were applied for $1 \mathrm{~h}$ at RT. Membranes were then washed and visualized using a Li-Cor Odyssey Infrared imaging system.

Cos 7 cell contraction assay. The Cos 7 cell contraction assay was adapted from protocols described previously (Takahashi et al., 1999). In brief, Cos7 cells were cultured in 6-well tissue culture plates and transfected with $0.5 \mu \mathrm{g}$ of the indicated expression plasmids using Lipofectamine 2000 (Invitrogen). After $12 \mathrm{~h}$, the cells were re-plated onto 96-well plates at a low density ( 150 cells per well) and grown for an additional $24 \mathrm{~h}$. AP-tagged Nogo66 conditioned media was added to each well and cells were incubated for $60 \mathrm{~min}$ at $37^{\circ} \mathrm{C}$ and then fixed with $4 \%$ paraformaldehyde for $15 \mathrm{~min}$. Cells were incubated with antibodies against NgR1 (1:1000) and HA (1:1000), then, either AlexaFluor 488-conjugated donkey anti-goat IgG and AlexaFluor 647-conjugated donkey anti-mouse $\operatorname{IgG}$ (1:2000; all from Invitrogen) were used to be visualized. Images were taken on a $10 \times$ objective in an automated high-throughput imager (ImageXpress Micro XLS, Molecular Devices) and NgR1-positive cell area was measured with using ImageJ.

Primary cortical neuron culture and cortical axon regeneration assay. Primary cortical cultures were established from E17 C57BL/6 WT mice, $\mathrm{NgR}^{+/-}, \mathrm{NgR}^{-/-}$, PlexinA2 ${ }^{+/-}, \mathrm{PlexinA}^{-1-}$, and $\mathrm{NgR1^{+/- }}$ PlexinA2 ${ }^{+/-}$mice. Cortices were dissected in ice-cold Hibernate E medium (catalog \#HE-Ca; BrainBits) and incubated in digestion HBSS medium containing $30 \mathrm{U} / \mathrm{ml}$ Papain (catalog \#LS003127; Worthington Biochemical), $1.5 \mathrm{~mm} \mathrm{CaCl} 2,2.5 \mathrm{~mm}$ EDTA, and $2 \mathrm{mg} / \mathrm{ml}$ DNaseI (cata$\log$ \#DN25; Sigma-Aldrich) at $37^{\circ} \mathrm{C}$ for $20 \mathrm{~min}$. Digested tissues were triturated and suspended in neurobasal-A media supplemented with B-27, GlutaMAX, and penicillin-streptomycin (all from Invitrogen). For immunoprecipitation assay, cells were plated on 6-well tissue culture plates coated with poly-D-lysine at a density of $1 \times 10^{5}$ cells per well.

The cortical axon regeneration assay was performed as described previously (Huebner et al., 2011). Neurons were plated on 96-well tissue culture plates coated with poly-D-lysine at a density of $2.5 \times 10^{4}$ cells per well in $200 \mu \mathrm{l}$ of neurobasal-A. At 8 DIV, 96-well cultures were scraped using a floating pin tool with FP1-WP pins (V\&P Scientific) and allowed to regenerate for another $48-60 \mathrm{~h}$ before fixing with $4 \%$ paraformaldehyde. Regenerating axons in the scrape zone were visualized using an antibody against $\beta$ III tubulin (1:2000, mouse monoclonal; catalog \#G712A, Promega). Growth cones were visualized by staining for F-actin using rhodamine-conjugated phalloidin (1:2000; catalog \#R415, Life Technologies). Cell density was visualized using nuclear marker DAPI $(0.1 \mu \mathrm{g} / \mathrm{ml}$; catalog \#4083, Cell Signaling Technology). Images were taken on a $10 \times$ objective in an automated high-throughput imager (ImageXpress Micro XLS, Molecular Devices) under identical conditions. Without knowledge of the experimental group, the regeneration zone was cropped to a $200 \mu \mathrm{m}$ width rectangle, the image was thresholded and neurite length was quantitated using ImageJ to determine the extent of axon regeneration. Measurements from different wells for the same condition in any one experiment were averaged together for one $n$ value, and statistics were calculated between cultures from $n$ embryos.

Mice and surgery. Age-matched adult (12 weeks) C57BL/6 wild-type, $\mathrm{NgR1}^{-+/-}$(Kim et al., 2004), PlexinA2 ${ }^{+/-}$(Shim et al., 2012) or $\mathrm{NgR1}^{-+/}$, PlexinA2 ${ }^{+/-}$mice were subjected to unilateral pyramidotomy (PyX) as described previously (Cafferty and Strittmatter, 2006). All animals received subcutaneous injection of buprenex $(0.01 \mathrm{mg} / \mathrm{kg}) 30$ min before surgery and were deeply anesthetized with ketamine (100 $\mathrm{mg} / \mathrm{kg})$ and xylazine $(15 \mathrm{mg} / \mathrm{kg})$ and placed in a supine position: an incision was made left of the trachea. Blunt dissection was performed to expose the skull base, and a craniotomy in the occipital bone allowed for access to the medullary pyramids. The dura mater overlaying the pyramids was pierced with a 30-gauge needle, and the left pyramid was cut with fine iridectomy scissors medially up to the basilar artery. The wound was closed in layers with 5.0 Vicryl. All animals received subcutaneous injection of $100 \mathrm{mg} / \mathrm{kg}$ ampicillin twice a day for the first $2 \mathrm{~d}$ after surgery. To trace the corticospinal tract (CST), biotin dextran amine (BDA) was injected bilaterally into the sensorimotor cortex 4 weeks after PyX. In each animal, $150 \mathrm{nl}$ of $10 \%$ solution of BDA was injected at each of the six 


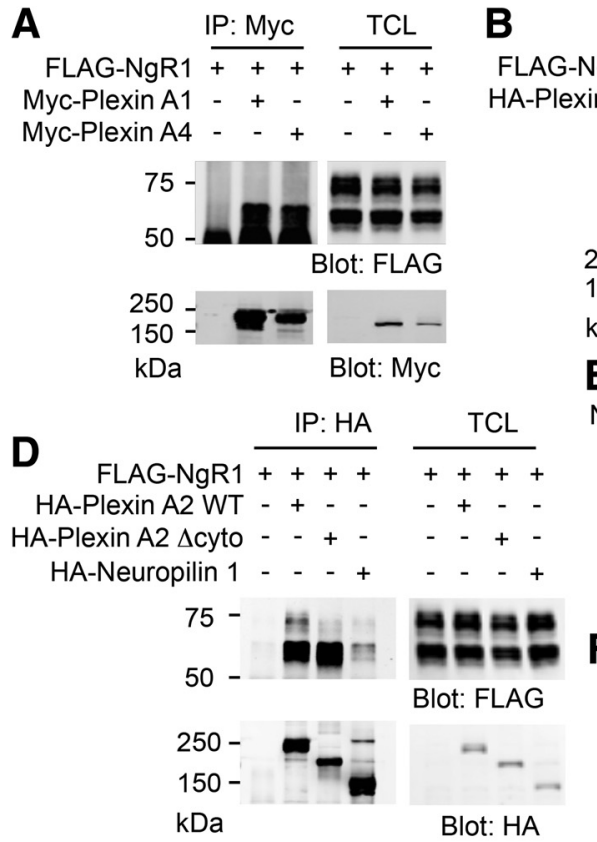

Blot: HA
IP: $\mathrm{HA} \frac{\mathrm{TCL}}{+++}$

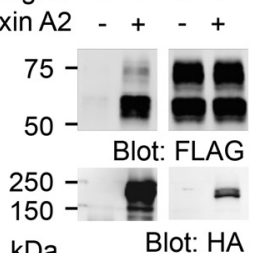

E IP: PlexA2 TCL Nogo22 -++ $75-$

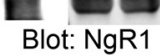

$250-$

$\mathrm{kDa}$

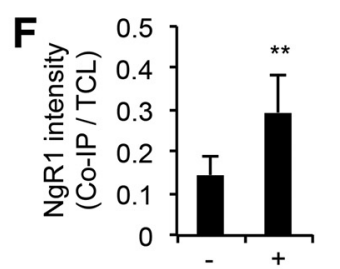

Nogo22
C IP: VSV $\frac{\text { TCL }}{++}$

VSV-Plexin A3 - + - +

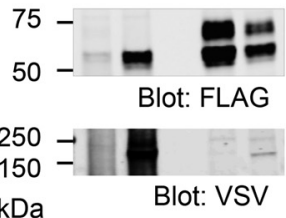

G IP: PlexA2 TCL

Nogo22 $++\frac{\text { TCL }}{-+}$

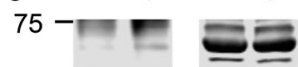

Blot: CRMP2

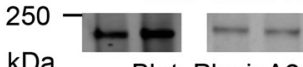

$\mathrm{kDa} \quad$ Blot: PlexinA2

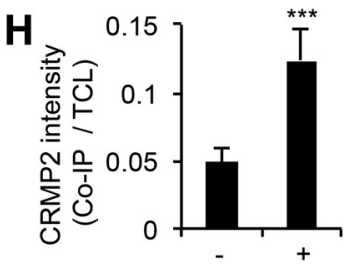

Nogo22

Figure 2. NgR1 interaction with CRMP2 and PlexinA2 driven by Nogo-A exposure. A-D HEK293T cells were transfected with indicated plasmid. At $36 \mathrm{~h}$ after transfection, cells were lysed and immunoprecipitated with indicated antibodies, and immunoblotted for individual antibodies. TCL, Total cell lysates. $\boldsymbol{E}$-H PlexinA2 immunoprecipitates from 21 DIV cortical neurons stimulated without or with Nogo22 (100 nM) for 5 min were resolved by SDS-PAGE and immunoblotted for NgR1 (E) and CRMP2 (G). The graphs show the quantification of NgR1 $(n=4 ; \boldsymbol{F})$ and CRMP2 $(n=$ $5 ; \boldsymbol{H})$ protein levels in the immunoprecipitates normalized to total cell lysate. Mean \pm SE. ${ }^{* *} p<0.01,{ }^{* * *} p<0.005$, Student's two-tailed $t$ test.

A

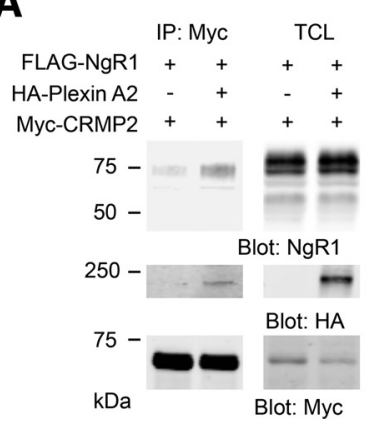

B

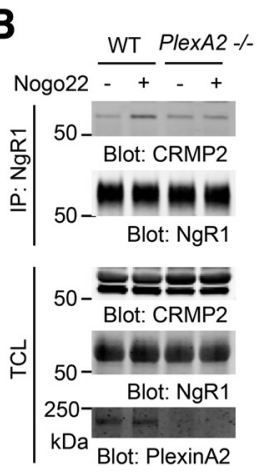

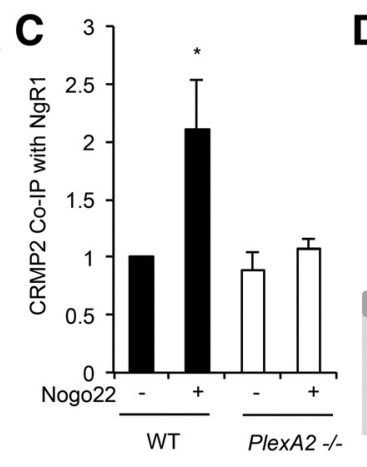

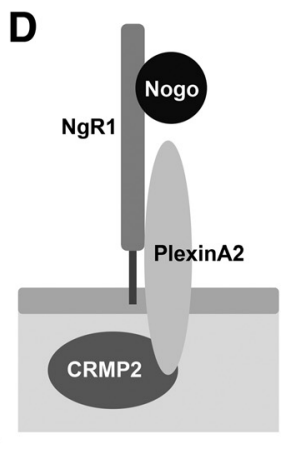

Figure 3. NgR1 forms ternary complex with PlexinA2 and CRMP2. A, HEK293T cells were transfected with FLAG-NgR1 and Myc-CRMP2 or with HA-PlexinA2. Myc immunoprecipitates were immunoblotted for NgR1, HA, and Myc. TCL, Total cell lysates. B, C, Twenty-one DIV cortical neurons from WT or PlexinA2 ${ }^{-/}$were stimulated without or with Nogo 22 (100 nm) for 5 min and then lysed. The lysate was immunoprecipitated with anti-NgR1 antibody and immunoblotted for CRMP2, NgR1, and PlexinA2. C, The graph shows the quantification of CRMP2 protein level in the immunoprecipitates normalized to total cell lysate $(n=3) .{ }^{*} p<0.05$, one-way ANOVA followed by Tukey's test. $\boldsymbol{D}$, Schematic model of Nogo-A-induced ternary complex of NgR1, PlexinA2 and CRMP2.

sites (coordinates from bregma in mediolateral/anterior-posterior format in mm: 1.0/0.0, 1.5/0.5, 1.5/0.5, 1.5/1.0, 1.0/-1.5, 1.5/-0.5, all at a depth of $0.6 \mathrm{~mm}$ into cortex) for a total of $900 \mathrm{nl}$ volume per hemisphere. Two weeks after the tracing, animals were killed by transcardial perfusion with PBS followed by $4 \%$ PFA. All procedures and postoperative care were performed in accordance with the guidelines of the Institutional Animal Use and Care Committee at Yale University.

Behavioral test. Surgery and behavioral tests were performed unaware of the genotype of the mice. Animals were tested $3 \mathrm{~d}$ before Pyx for baseline function, 3 and $28 \mathrm{~d}$ postlesion ( $\mathrm{dpl}$ ). The grid-walking test was performed as described previously (Starkey et al., 2005). Mice were placed on an elevated $300 \times 200 \mathrm{~mm}$ metal grid with $10 \times 10 \mathrm{~mm}$ square space and allowed to freely explore the grid for $3 \mathrm{~min}$. Mice were videotaped via reflection from mirror placed under the grid and scored for the percentage of impaired steps of the first 50 steps taken with left and right hind limbs individually. Impaired steps were scored that the limb fell between the rungs or an incorrectly placed step where either the ankle or tips were placed on the rungs without proper grasping, or when the limb was correctly placed but slipped off during weight bearing.

Histology and immunostaining. Spinal cords were dissected, postfixed in $4 \%$ paraformaldehyde at $4^{\circ} \mathrm{C}$, and subsequently embedded in $10 \%$ gelatin. Serial sections $(40 \mu \mathrm{m})$ were collected on a vibratome (VT1000S, Leica). Transverse sections at cervical enlargements were blocked and permeabilized with $10 \%$ normal donkey serum and $0.3 \%$ Triton X-100 in PBS for $1 \mathrm{~h}$. Then, sections were incubated with anti-PKC $\gamma(1: 1000)$ antibody and visualized with AlexaFluor 488-conjugated secondary antibody (1:1000), or processed for BDA with streptavidin and tyramide amplification (PerkinElmer Life Sciences) and stained sections were imaged by using the Zeiss LSM 800 confocal microscope with $20 \times$ lens. PKC $\gamma$-positive signal intensity in dorsal columns from each side of each 

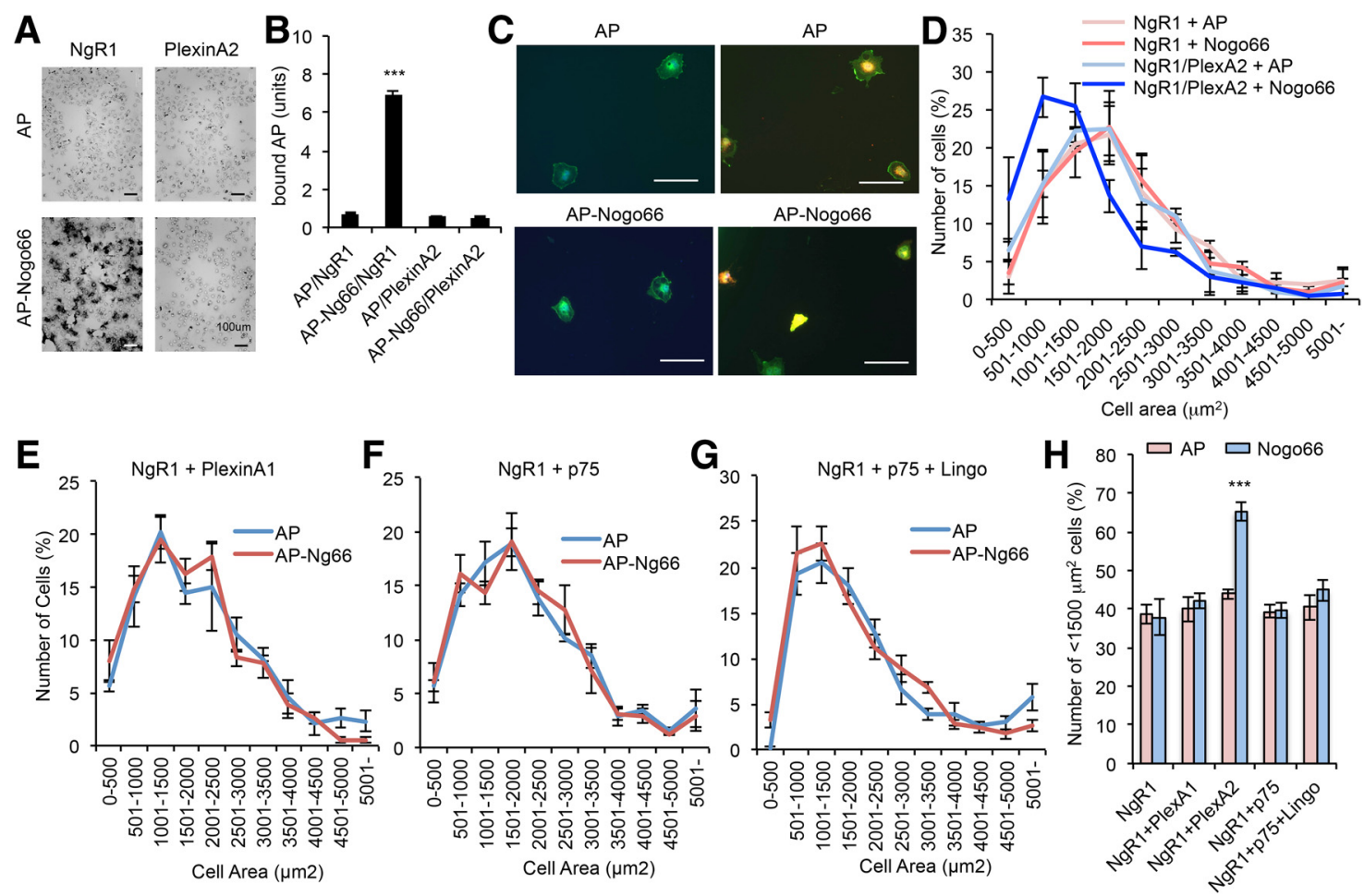

Figure 4. NgR1/PlexinA2 complex is sufficient for Nogo-A-induced Cos7 cell contraction. A, Cos7 cells transfected with NgR1 or PlexinA2 were cultured for $36 \mathrm{~h}$ and incubated with AP or AP-tagged Nogo66 for 60 min. Binding was visualized with AP substrate BCIP/NBT (left). Scale bars, $100 \mu \mathrm{m}$. B, AP substrate density was measured using ImageJ. Error bars represent SEM; $n=10$. ${ }^{* * *} p<0.005$, one-way ANOVA followed by Tukey's test. C, Cos7 cells were transfected with NgR1 or NgR1 plus HA-PlexinA2. After $12 \mathrm{~h}$, the cells were re-plated onto 96 -well plates at 150 cells per well and grown for an additional $24 \mathrm{~h}$. Then, cells were incubated with AP or AP-tagged Nogo66 for 60 min and stained with NgR1 (green) and HA (red). Scale bars, $100 \mu \mathrm{m}$. D, The NgR1-positive cell area was measured with using ImageJ. Data are presented as the mean \pm SE; $n=3 . \boldsymbol{E}-\mathbf{G}$, Cos7 cells were transfected with NgR1 plus PlexinA1 (E), p75 (F), or p75 and Lingo $(\boldsymbol{G})$. After $12 \mathrm{~h}$, the cells were re-plated onto 96-well plates at 150 cells per well and grown for an additional $24 \mathrm{~h}$. Then, cells were incubated with AP or AP-tagged Nogo66 for 60 min and stained with NgR1 and NgR1-positive cell area was measured with using ImageJ. Data are presented as the mean $\pm \mathrm{SE} ; n=3(\boldsymbol{E}), n=5(\boldsymbol{F}, \boldsymbol{G})$. $\boldsymbol{H}$, Cos7 cells transfected with indicated plasmids were incubated with AP or AP-Nogo66, and cells were fixed and stained with NgR1 antibody. NgR1-positive cell area was measured using ImageJ and number of $<1500 \mu \mathrm{m}^{2}$ cells was summarized. Error bars represent $\mathrm{SEM} ; n=3(\mathrm{NgR1}$, NgR1 + PlexinA2, NgR1 + PlexinA2), $n=4$ (NgR1+p75, NgR1+p75+Lingo).*** $p<0.005$, one-way ANOVA followed by Tukey's test.

section (4 sections/mouse) was measured by using National Institutes of Health (NIH) ImageJ $1.50 \mathrm{~h}$. BDA-labeled fibers in the cervical enlargement of spinal cord gray matter from each side of each section (4 sections/mouse) were analyzed using ImageJ with AxonTracer (Patel et al., 2018) by an observer unaware of genotype. Measurements from different sections of one animal were averaged together for one $n$ value, and statistics were calculated between $n$ mice. The CST fiber length on the denervated side was divided by that measured on the intact site for normalization.

Experimental design and statistical analysis. For statistical comparison between two groups, a two-tailed $t$ test assuming unequal variance was used. For comparisons among three or more groups, one-way ANOVA was used to compare each group mean with the control mean with Dunnett's correction, or multiple comparisons were corrected by Tukey's method. All statistical analyses were specified in the figure legends using Excel and Prism software. Statistical significance was set at $p \leq 0.05$. All data are mean \pm SEM. To set the sample size for the in vivo study, we performed a power analysis using our previous unilateral Pyx data from $\mathrm{NgR1}^{-1-}$ (Cafferty and Strittmatter, 2006) and PlexinA2 ${ }^{-1-}$ (Shim et al., 2012) mice. That analysis indicated that 7-9 animals are required to detect a $50 \%$ difference in axon sprouting between two genotype groups with $\alpha=0.5$ and power $=0.8$.

The mouse cohorts for PyX were based on littermate matching without regard to sex, and the male-female number was 6:3 for WT, 3:5 for $\mathrm{NgR1}^{-+/}, 4: 3$ for PlexinA2 $2^{+/-}$, and 2:5 for $\mathrm{NgR}^{-+/-}$, PlexinA2 ${ }^{+/-}$. When combining outcomes from all four genotypes at $28 \mathrm{~d}$ after PyX, there was no significant difference between males and females with regard to CST axonal sprouting or grid walking errors (data not shown). No animal exclusions were made. All behavioral and histological analyses were conducted without knowledge of treatment group. For histological analyses, measure- ments from different sections of one animal were averaged together for one $n$ value, and statistics were calculated between $n$ mice. Statistical details for Figures 7, $E$ and $F$, and 8, $A$ and $B$, are provided in Table 1 .

Data availability. All relevant data that support our experimental findings are available from the authors.

\section{Results}

\section{Identification of $\mathrm{NgR} 1$ interacting proteins by} Nogo-A stimulation

To identify proteins that form a physical complex with NgR1 induced by ligand binding, we stimulated 21 DIV cortical neurons with the Nogo-A-derived ligand Nogo22 (Huebner et al., 2011) for $5 \mathrm{~min}$, and then the lysate was immunoprecipitated with anti-NgR1 antibody. The immunoprecipitates were resolved by SDS-PAGE and visualized by silver staining (Fig. 1A). $\mathrm{NgR} 1$ complexes contain a number of proteins with increased abundance after stimulation with recombinant Nogo22, a $22 \mathrm{kDa}$ C-terminal fragment of Nogo-A containing the Nogo-66 peptide and surrounding additional NgR1-interacting domains (Laurén et al., 2007; Huebner et al., 2011). Protein bands associated with ligand stimulation were excised, digested with trypsin, and peptides analyzed by LC/MS to determine their identity (Fig. 1B). The interaction of several proteins with NgR1 was confirmed by subsequent immunoprecipitation and immunoblot (Fig. 1C,D). Specifically, CRMP2, CRMP4, Myh10, and Jup form a complex with NgR1 significantly increased by Nogo22 stimulation in cortical neurons. Interaction between Hspa8 and $\mathrm{NgR} 1$ is also detectable, but the binding is not changed by treatment with 

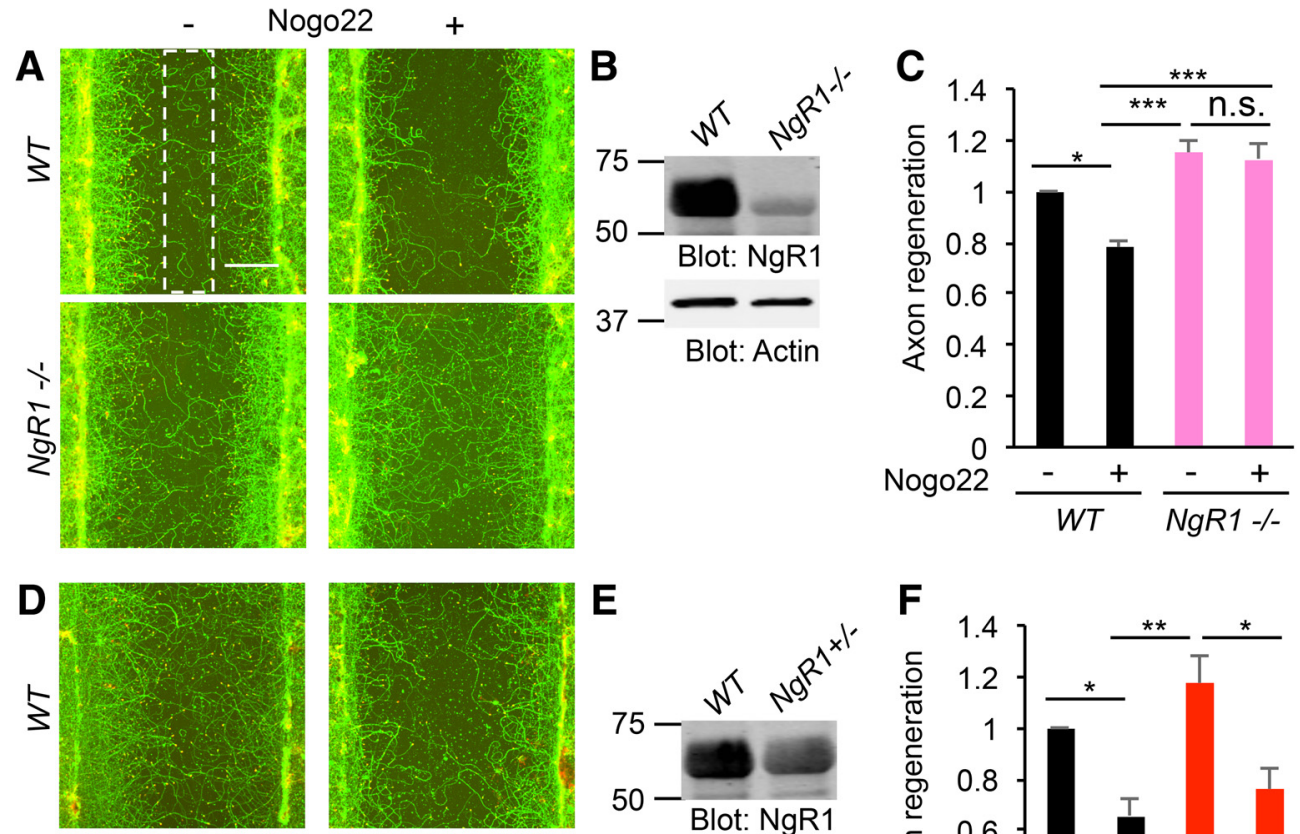

\section{E}
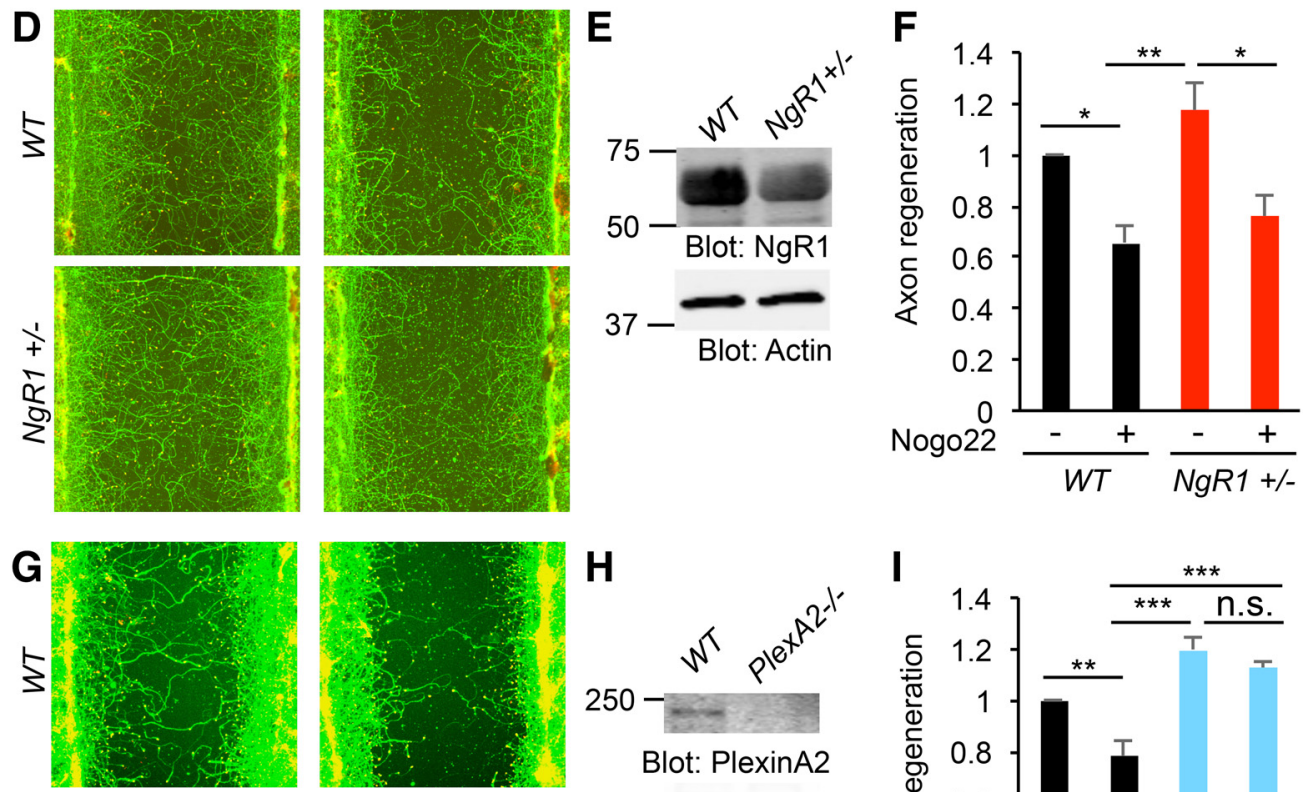

H
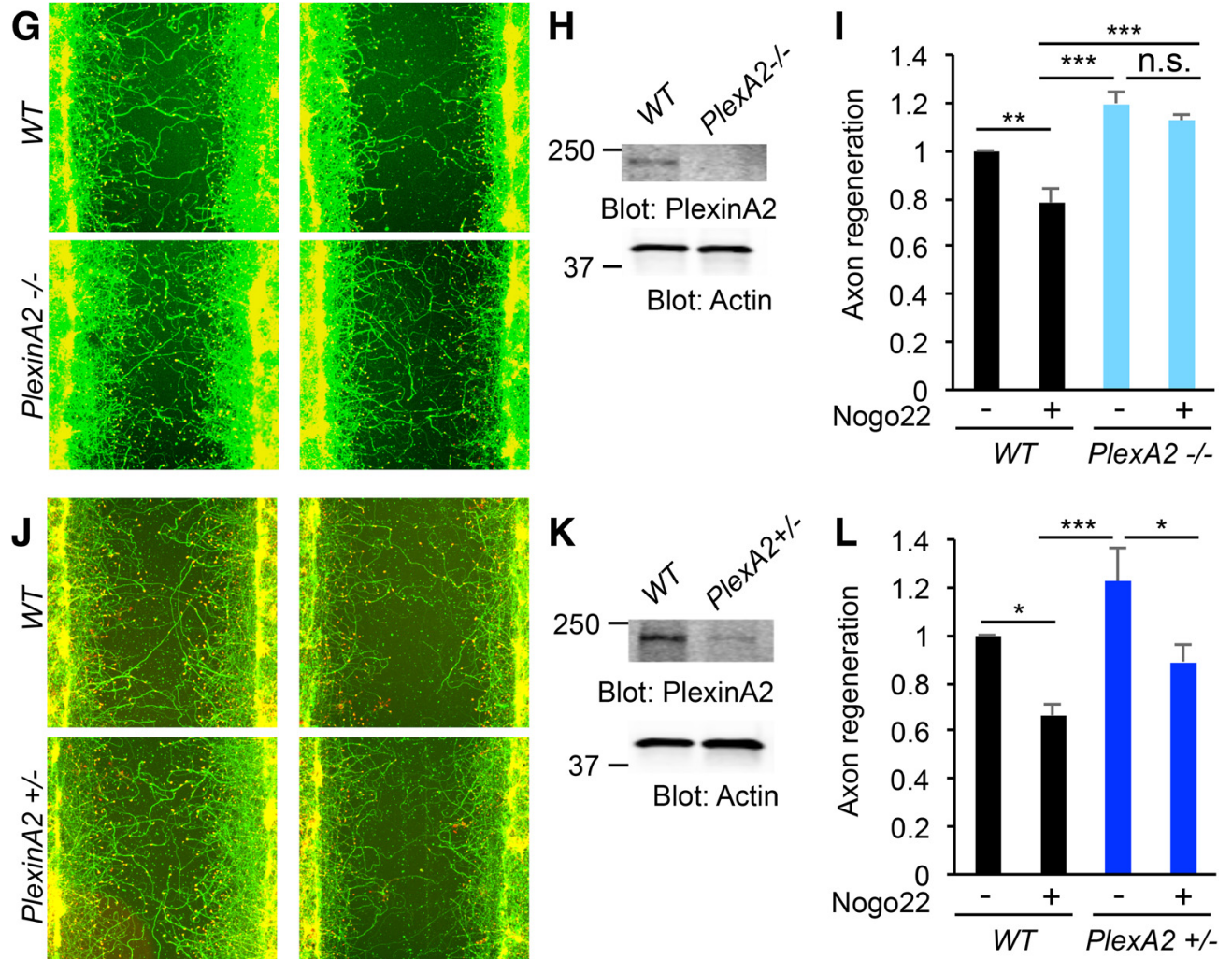

Figure 5. $\mathrm{NgR1} /$ PlexinA2 signaling mediates Nogo-A inhibition of axon regeneration in vitro. $\boldsymbol{A}-\boldsymbol{L}$, Cortical neurons from WT, $\mathrm{NgRT}^{-/-}(\boldsymbol{A}-\boldsymbol{C}), \mathrm{NgR1}^{+/-}(\boldsymbol{D}-\boldsymbol{F}), \mathrm{PlexinA2}^{-/-}(\mathbf{G}-\boldsymbol{I})$, and PlexinA2 $2^{+/-}(\boldsymbol{J}-\boldsymbol{L})$ were scraped at $8 \mathrm{DIV}$ and allowed to regenerate for $3 \mathrm{~d}$ in the presence of Nogo22 (100 nM). The microphotographs show $\beta$ III tubulin (in axons; green) and phalloidin (to stain $\mathrm{F}$-actin; red). The $200 \mu \mathrm{m}$ width rectangle in which axon length was measured is shown as a white dotted box. Scale bars: $A, D, G, J, 200 \mu \mathrm{m}$. Insets, Imunoblots of lysates cultures with anti-NgR1, PlexinA2, and Actin antibodies for each of the genotypes $(\boldsymbol{B}, \boldsymbol{E}, \boldsymbol{H}, \boldsymbol{K})$. The graph shows quantification of axonal regeneration normalized to WT control (Nogo22-). Error bars represent SEM; $\mathrm{NgRT}^{-/-}(n=4 ; \boldsymbol{C}), \mathrm{NgRT}^{+/-}(n=3 ; \boldsymbol{F})$, PlexinA2 ${ }^{-1-}(n=3 ; \boldsymbol{I})$, and PlexinA2 ${ }^{+/-}(n=5 ; L)$ biological replicates, with one value for each of $n$ embryos. n.S., not significant, ${ }^{*} p<0.05,{ }^{* *} p<$ $0.01,{ }^{* * *} p<0.005$, one-way ANOVA followed by Tukey's test. 

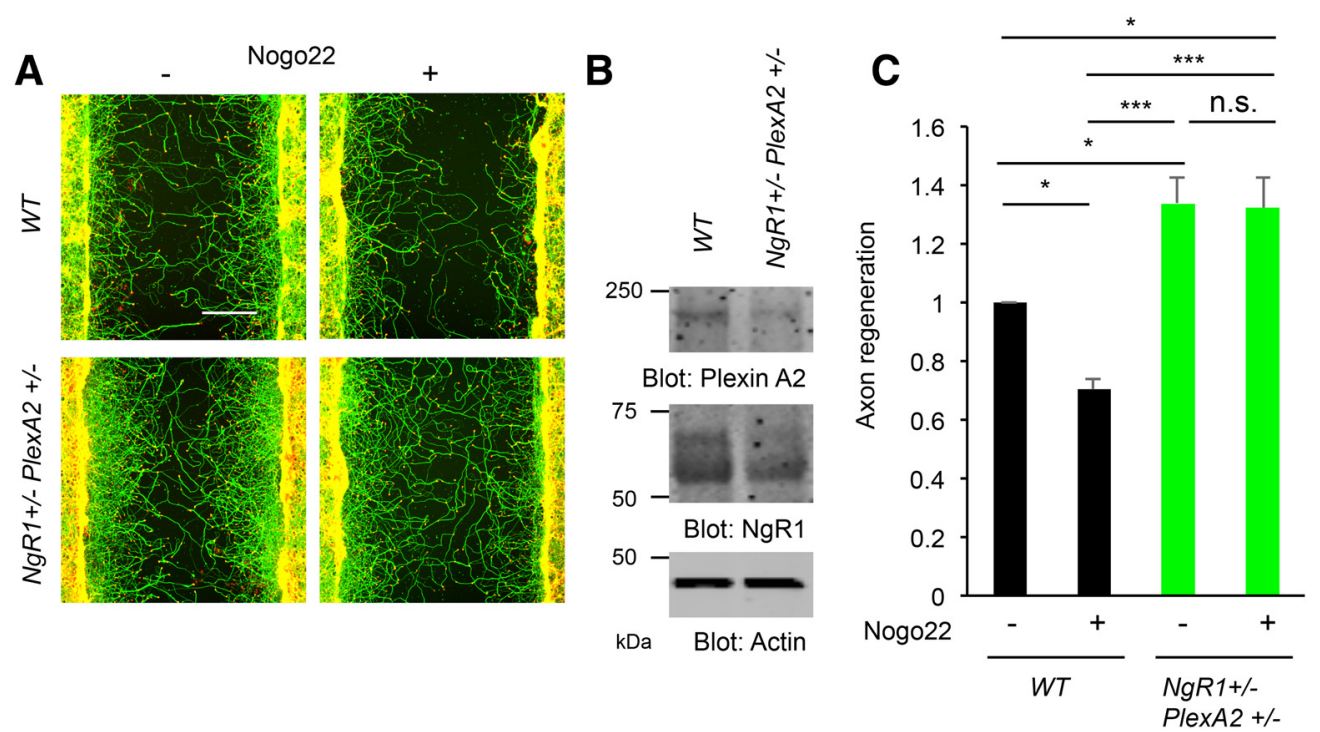

Figure 6. $\mathrm{NgR} 1^{+/-}$PlexinA2 $2^{+/-}$neuron shows enhanced axonal regeneration in vitro. $A$, Cortical neurons from WT and $\mathrm{NgR}^{+/-}$PlexinA2 ${ }^{+/-}$were scraped at 8 DIV and allowed to regenerate for $3 \mathrm{~d}$ in the presence of Nogo22 $(100 \mathrm{~nm})$. The microphotographs show $\beta$ III tubulin (in axons; green) and phalloidin (to stain F-actin; red) to illustrate the growth cones of cortical neurons in the middle of the scraped area. Scale bar, $200 \mu \mathrm{m}$. B, Immunoblots of lysates cultures with anti-NgR1, PlexinA2, and actin antibodies. C, The graph shows quantification of axonal regeneration normalized to WT control (Nogo22-). Error bars represent SEM; $n=5$ biological replicates from different embryos. n.s., not significant, ${ }^{*} p<0.05,{ }^{* * *} p<0.0005$, one-way ANOVA followed by Tukey's test.

Nogo22 (data not shown). Previous work has revealed functional coupling of NgR1 and CRMPs in EAE-related axonal damage, and CRMPs had been shown to participate in MAG-induced axonal growth inhibition (Mimura et al., 2006; Petratos et al., 2012). However, no direct physical association between NgR1 and CRMPs has been documented in the literature. We chose CRMPs for further study, because CRMP proteins are known regulators of axon guidance and extension.

\section{NgR1 forms a complex with CRMP2 and PlexinA2 after Nogo-A stimulation}

The CRMPs are a family of cytosolic proteins known to form a complex with transmembrane Plexin family receptor proteins, and to transduce Semaphorin signals for axon guidance, dendritic branching and synapse formation (Deo et al., 2004; Schmidt and Strittmatter, 2007; Schmidt et al., 2008). In the case of soluble Sema3 ligands, the coreceptor neuropilin binds the guidance cue and interacts with PlexinA proteins in cis- (Takahashi et al., 1999). In contrast to the Plexins, mature NgR1 is a GPI-anchor protein lacking an intracellular domain, and therefore requires one or more coreceptors to transduce signals to the cell interior. For these reasons, we investigated the possibility that Plexin family proteins interact with NgR1 functioning as coreceptors in the same manner as neuropilin/Plexin complexes for Sema3's. FLAG-tagged NgR1 was expressed without or with epitope-tagged PlexinA1, 2, 3, or 4 in HEK293T cells and examined by coimmunoprecipitation assay (Fig. $2 A-C$ ). Previously, we have reported that overexpressed NgR1 in HEK cells migrates by SDS-PAGE as a doublet, and the more slowly migrating upper band is the mature protein expressed on the cell surface (Sekine et al., 2018a). As shown in Figure 2B, PlexinA2 interacted with both upper and lower NgR1 bands, however, PlexinA1, 3, and 4 associated with only the lower band of NgR1 (Fig. $2 A-C$ ). These data suggest that PlexinA2, compared with PlexinA1, 3, and 4, selectively forms a cell surface complex with expressed NgR1 in HEK293T cells. We also assessed whether NgR1 interacts with transmembrane neuropilin1, which associates with PlexinA2 in
Sema3 signal transduction. In HEK293T cells, overexpressed NgR1 forms a complex with PlexinA2 WT, but not neuropilin1 (Fig. $2 D$ ). PlexinA2 lacking the cytosolic domain ( $\Delta$ cyto) is incapable of signaling and also fails to associate with $\mathrm{NgR} 1$, suggesting that Plexin conformational state contributes to affinity (Fig. 2D). To evaluate the association of endogenous proteins, cortical neurons were treated without or with Nogo22 for $5 \mathrm{~min}$ and then coimmunoprecipitated. The NgR1 immunoreactivity in antiPlexinA2 immunoprecipitates is greater after ligand stimulation (Fig. 2 E, F). Furthermore, CRMP2 association with PlexinA2 was increased by NgR1 ligand stimulation in cultured neurons (Fig. $2 G, H)$, paralleling the increased association of NgR1 with CRMP2 (Fig. 1C). These data indicate that NgR1 forms a ternary complex with CRMP2 and PlexinA2 after ligand binding.

In HEK293T cells, CRMP2 were able to interact with NgR1 but only when coexpressed with PlexinA2 (Fig. 3A). In this overexpression system, NgR1 ligand was not essential for association. Furthermore, the CRMP2 association with NgR1 immunoprecipitates stimulated by Nogo22 treatment in WT cortical neurons, fails to occur in PlexinA $2^{-/-}$neurons (Fig. $3 B, C$ ). Thus, a ternary complex of NgR1 with PlexinA2 and CRMP2 is stimulated by NgR1 ligand stimulation in neurons (Fig. 3D).

\section{NgR1/PlexinA2 complex is sufficient for Nogo-A-induced Cos7 cell contraction}

The evidence that NgR1 associates with intracellular CRMP2 via PlexinA2 after ligand binding suggests that PlexinA2 transduces the Nogo-A-NgR1 signal into the cell as a co-receptor. This NgR1 signaling hypothesis parallels the role of neuropilin in Sema3 signaling. To consider this possibility, we conducted a Cos7 contraction assay. PlexinA1/neuropilin1 expressing Cos7 cells contract their cell perimeter in response to Sema3A mediated by CRMP signaling (Takahashi et al., 1999). Using this nonneuronal cell system, we examined whether Nogo-A-NgR1 signaling is able to alter Cos7 cell morphology. As a first step, we verified that the Nogo ligand binds to NgR1 but has no direct affinity for PlexinA2 using an alkaline phosphatase (AP)-Nogo66 

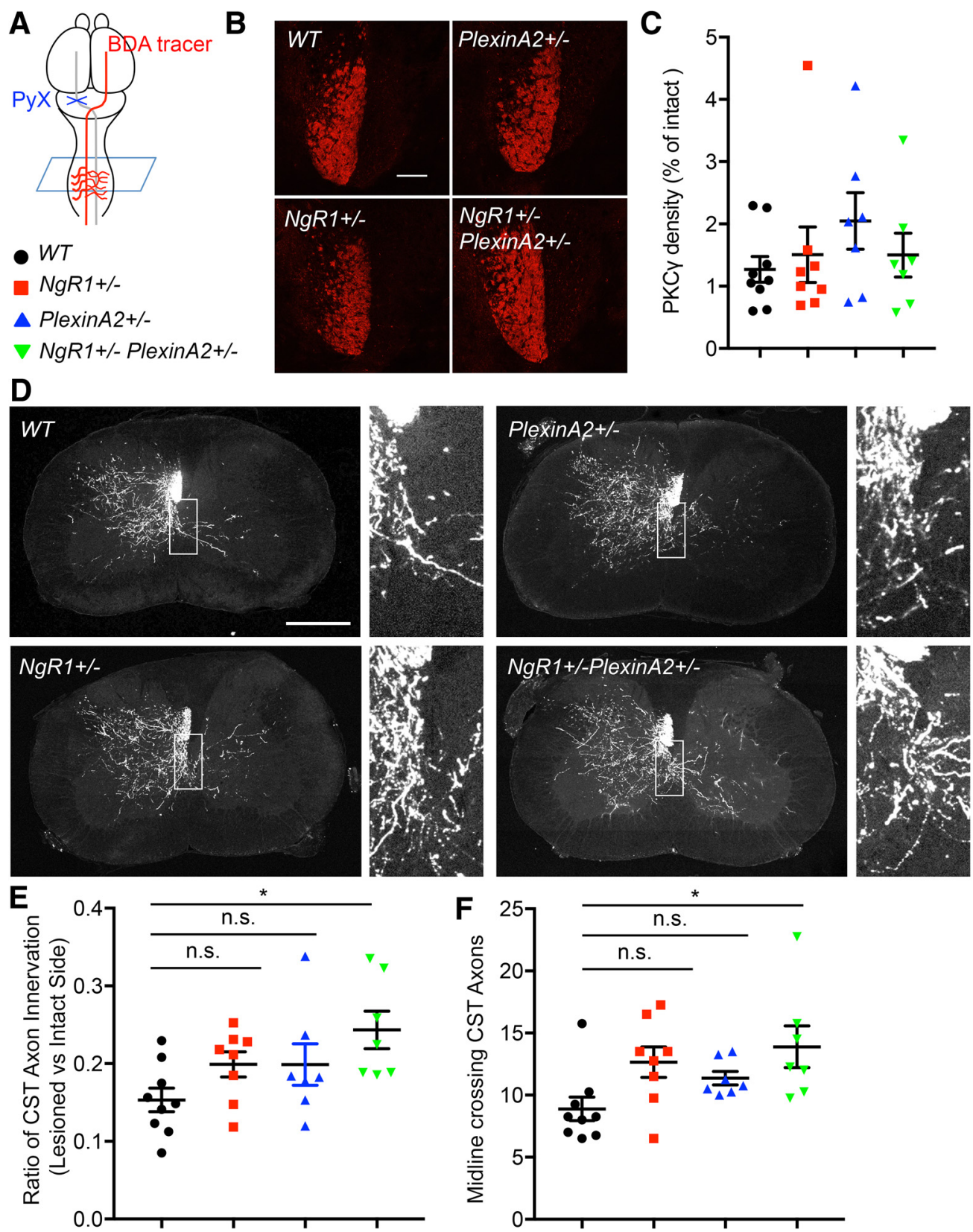

Figure 7. Genetic coupling between NgR1 and PlexinA2 limits corticospinal axon sprouting after injury. $A$, Schematic image of unilateral pyramidotomy surgery. $B$, PKC $\gamma$ density in dorsal columns at cervical cord coronal sections from PyX mice was imaged. The intact side is bright and the lesioned side shows little or no staining. C, Each marker shows percentage of density of injured side relative to intact side in each animal. Data are also presented as mean with SEM. No significant differences between groups with one-way ANOVA followed by Tukey's test. $\boldsymbol{D}$, Representative image of BDA traced fibers in cervical spinal cord. Scale bars, $500 \mu \mathrm{m}$. Right, High-magnification view of white boxes shown in images. $E$, The graph shows the length of CST axons in gray matter on the denervated side of the cervical spinal cord. Values are normalized by the intact side axon length in the same sections from pyramidotomized WT $(n=9), \mathrm{NgR1^{+/- }}(n=8), P l e x i n A 2^{+/-}(n=$ 7), and $\mathrm{NgR1}^{+/-}$PlexinA2 ${ }^{+--}(n=7)$ mice. Error bars represent SEM. ${ }^{*} p<0.05$, one-way ANOVA followed by Tukey's multiple-comparisons test. Results for four sections from each mouse were averaged to create one value for each of $n$ mice. $\boldsymbol{F}$, The graph shows the number of midline crossing of uninjured CST axon from pyramidotomized WT $(n=9), N g R 1^{+/-}(n=8), P l e x i n A 2^{+/-}(n=$ 7), and $\mathrm{NgRT}^{+/-}$PlexinA2 ${ }^{+/-}(n=7)$ mice. Error bars represent SEM. n.s., not significant, ${ }^{*} p<0.05$, one-way ANOVA followed by Tukey's multiple-comparisons test.

fusion protein (Fig. $4 A, B$ ). This is consistent with a potential role for PlexinA2 as a coreceptor for Nogo-A in a complex with ligand-binding NgR1. For morphologic assays, Cos7 cells transfected with NgR1 or NgR1 plus PlexinA2 were incubated with AP or AP-Nogo66 for $1 \mathrm{~h}$ at $37^{\circ} \mathrm{C}$, then fixed and visualized staining with NgR1 antibody. Without any treatment, NgR1 and NgR1/ PlexinA2-expressing Cos7 cells show no morphologic change (data not shown). Furthermore, neither AP nor Nogo66 treatment has any effect on NgR1-expressing Cos7 cell morphology (Fig. $4 C, D$ ). In contrast, NgR1/PlexinA2-expressing Cos7 cells exhibit significantly reduced cell surface area after incubation with Nogo66 but not AP. Consistent with IP experiment in Figure $2 A$, another Plexin family protein, PlexinA1, has no effect on Cos7 contraction induced by Nogo66 incubation (Fig. 4E,H). These data suggest that PlexinA2 functions as coreceptor for $\mathrm{NgR} 1$ in Cos7 cells. In parallel, we examined p75NTR and Lingo, which have been suggested to function as NgR1 co-receptors, in this Cos7 contraction assay. Cos7 cells expressing NgR1/p75NTR or NgR1/p75NTR/Lingo show no morphologic change by Nogo66 treatment (Fig. $4 F-H$ ). 

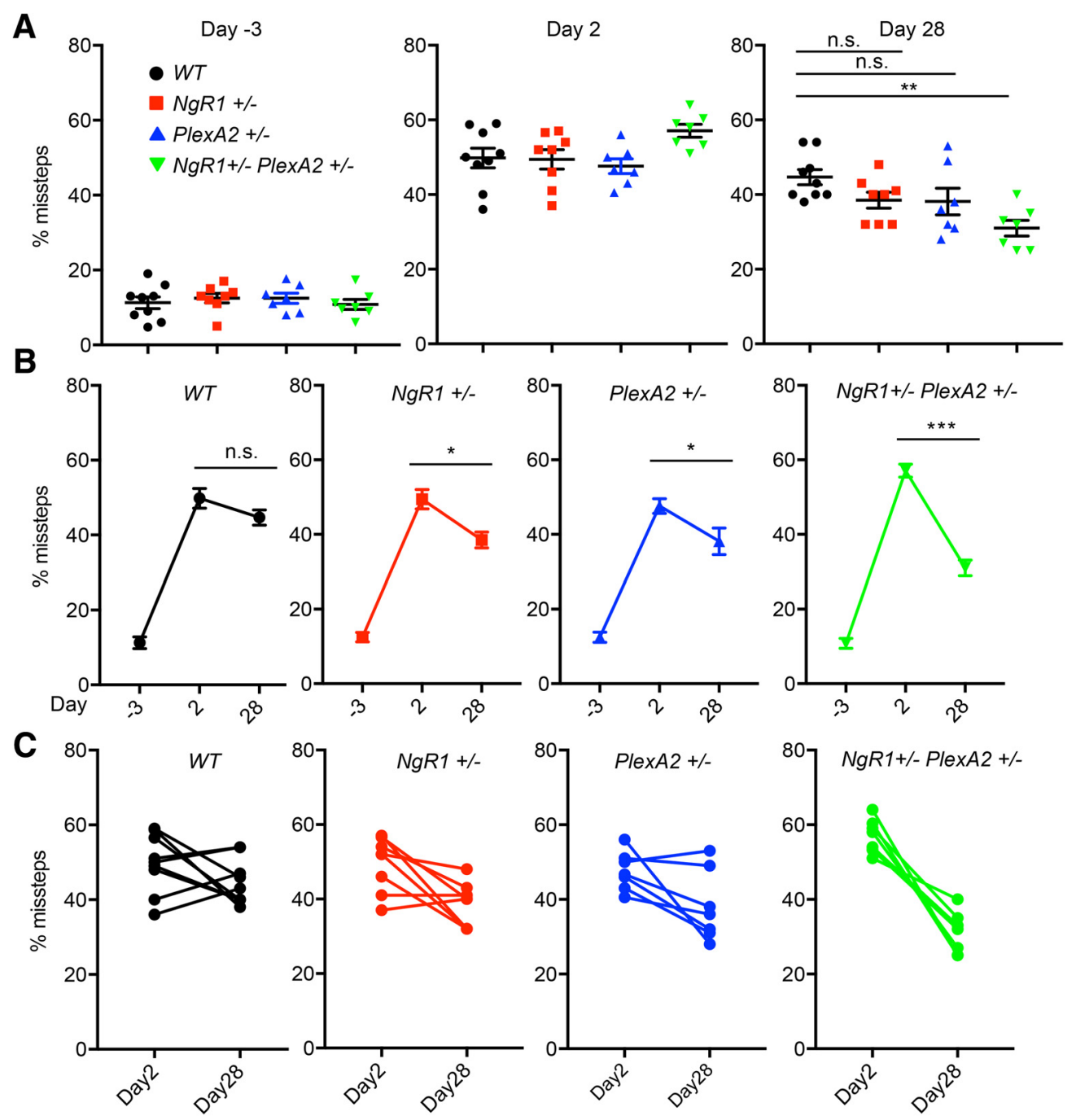

Figure 8. Enhanced behavioral recovery in double-heterozygous $\mathrm{NgR} 1^{+/-}$PlexinA2 ${ }^{+/-}$mice after pyramidotomy. $A$, Grid walk test at indicated days before or after PyX of WT $(n=9)$, $\mathrm{NgRT}^{+/-}(n=8)$, PlexinA2 $2^{+/-}(n=7)$, and $\mathrm{NgR1}^{+/-}$PlexinA2 $^{+/-}(n=7)$ mice. Each marker shows percentage of missed steps from average of right (injured side) forelimb and hindlimb of each animal. Error bars represent SEM. n.s., not significant, ${ }^{* *} p<0.01$, one-way ANOVA followed by Tukey's multiple-comparisons test. $B, C$, The graphs show percentage of missed step on right limbs of grid walk test at indicated days for average of each genotype (n.s., not significant, ${ }^{*} p<0.05,{ }^{* * *} p<0.005$, paired $t$ test; $\boldsymbol{B}$ ) and individual animal of each genotype (C).

\section{NgR1/PlexinA2 signaling mediates Nogo-A-mediated axon regeneration in vitro}

As PlexinA2 has a functional role in Nogo-A-mediated NgR1 signaling transduction in non-neuronal Cos7 cell, we conducted a neuronal in vitro axon regeneration assessment with cultured cortical neurons (Huebner et al., 2011; Sekine et al., 2018b). E17 mouse derived cortical neurons were cultured for $8 \mathrm{~d}$ and scraped with a metal pin tool for axotomy, and then incubated with Nogo22 for $3 \mathrm{~d}$ to assess axon regeneration. As reported previously (Huebner et al., 2011), Nogo22 significantly suppresses axonal regeneration in WT neurons, while $\mathrm{NgR}^{-/-}$neurons show no inhibition of regeneration by Nogo22 (Fig. $5 A-C$ ). Deletion of a single allele of $\mathrm{NgR1}\left(\mathrm{NgR1}^{+-}{ }^{-}\right)$fails to protect from Nogo22induced inhibition of axonal regeneration (Fig. $5 D-F$ ). Loss of one or two PlexinA2 alleles phenocopies the $\mathrm{NgR} 1$ allele loss pattern. Specifically, Nogo22-mediated suppression of axonal regeneration is abolished in PlexinA2 $2^{-/-}$neurons (Fig. 5G-I) and heterozygous $\left(P l e x i n A 2^{+/-}\right.$) neurons exhibit Nogo22-inhibited axonal regeneration similar to WT (Fig. $5 J-L$ ).

Next, we sought to determine whether there is a genetic interaction between $\mathrm{NgR} 1$ and PlexinA2 with regard to Nogo-
A-inhibited axon regeneration. Removal of single allele of either $N g R 1$ or PlexinA2 does not block axonal regeneration by Nogo22, but deletion of one allele of both $\mathrm{NgR} 1$ and PlexinA2 $\left(\mathrm{NgR}^{+/-} \mathrm{PlexinA} 2^{+/-}\right)$in double-heterozygous neurons abolishes Nogo22 suppression of axon regeneration (Fig. 6A$C)$. Together, these data demonstrate a genetic interaction between $\mathrm{NgR} 1$ and PlexinA2 in mediating Nogo-A-induced biochemical signaling in neurons, as suggested by the biochemical evidence for a ternary complex with CRMP2.

\section{Genetic coupling between $\mathrm{NgR} 1$ and PlexinA2 limits} corticospinal fiber sprouting after injury

After lesions of the CST at the medullary pyramid, $\mathrm{NgR}^{-/-}$mice exhibit greater axonal sprouting of the unlesioned CST across the midline to the contralateral side as compared with WT animals (Cafferty and Strittmatter, 2006). Unilaterally pyramidotomized PlexinA $2^{-1-}$ mice exhibit the same injury-induced CST sprouting after PyX (Shim et al., 2012), although the relevant ligand for this PlexinA2 phenotype is not defined. Based on genetic interaction between $\mathrm{NgR} 1$ and PlexinA2 with regard to in vitro axon regeneration, we sought to examine whether their interaction is 

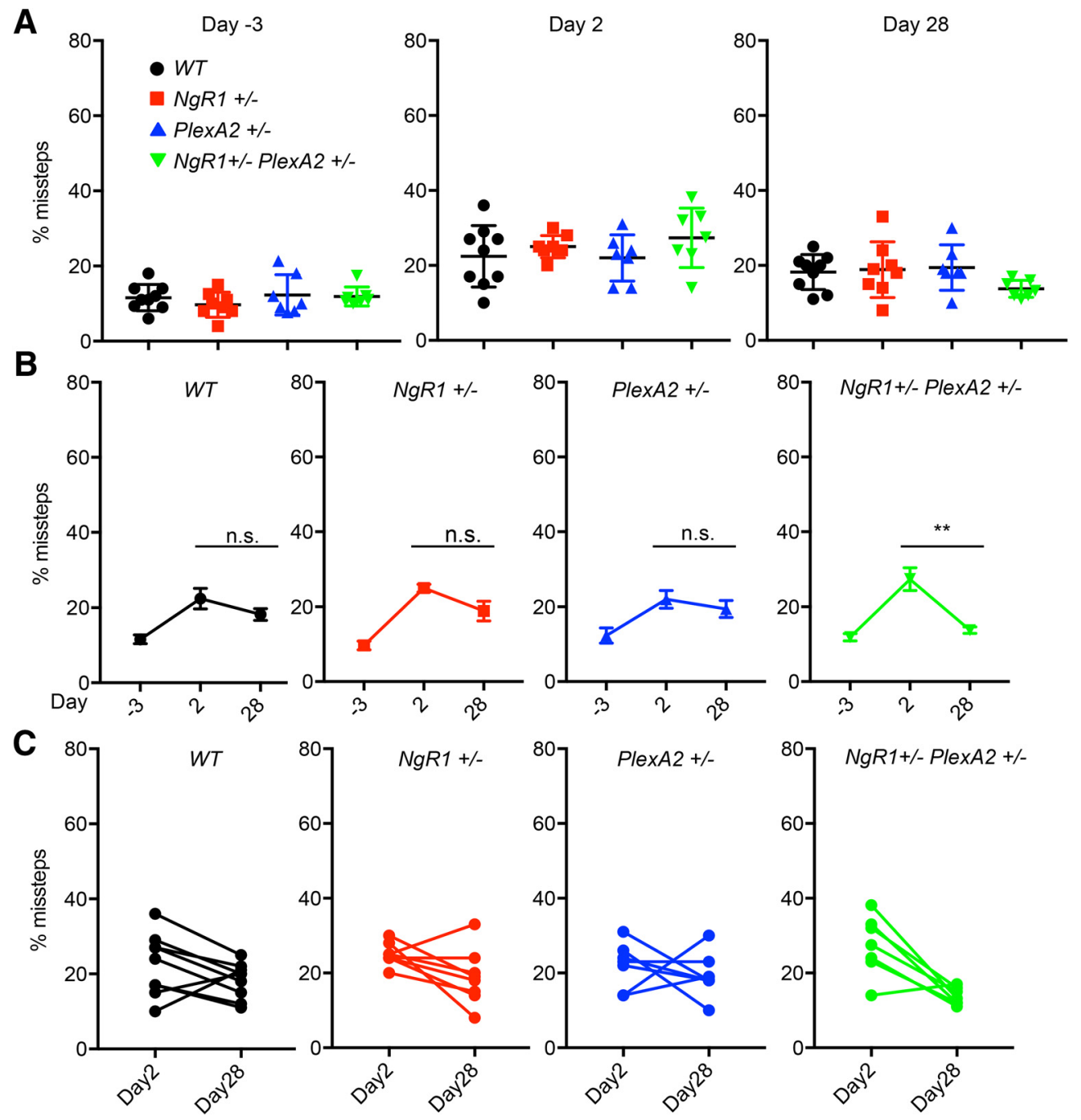

Figure 9. Intact side function after PyX is weakly affected and recovery is limited by interaction of $\mathrm{NgR1}$ and PlexinA2. A, Grid walk test at indicated days before or after PyX of WT ( $n=9$ ),

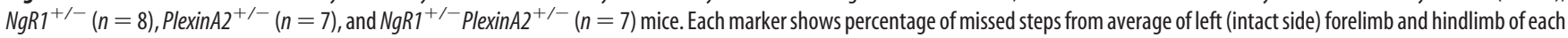
animal. Error bars represent SEM. No significant differences between groups with one-way ANOVA followed by Dunnett's multiple-comparisons test. $\boldsymbol{B}$, $\boldsymbol{C}$, The graphs show percentage of missed step on left limbs of grid walk test at indicated days for average of each genotype (n.s., not significant, ${ }^{* *} p<0.01$, paired $t$ test without correction for testing across 4 genotypes; Table 1; $\boldsymbol{B}$ ) and individual animal of each genotype $(\boldsymbol{C})$.

involved in CST sprouting after PyX. We created PyX lesions in WT, $\mathrm{NgR}^{+/-}$, PlexinA2 $2^{+/-}$, and $\mathrm{NgR1}^{+/-} \mathrm{PlexinA2}^{+/-}$mice. BDA was injected into the intact cortex at Day 28 after injury to assess the sprouting CST axons (Fig. 7A). All groups were killed 2 weeks after BDA injection for histological analysis. Protein kinase $\mathrm{C}$ gamma (PKC $\gamma$ ) immunoreactivity in the contralateral ventral dorsal column was measured at cervical cord in all groups and confirmed $>95 \%$ ablation of the CST (Fig. 7 B, C). BDA-positive sprouting CST axon length in the cervical cord was measured and normalized to ipsilateral CST fibers as a measure of lesion-induced sprouting axons. Pyramidotomized double-heterozygous $\mathrm{NgR}^{+/-}$ PlexinA $2^{+-}$mice show significantly increased lesion-induced innervation compared with $\mathrm{WT}$, phenocopying previous singlehomozygous mice. In contrast, neither the single-heterozygous $\mathrm{NgR}^{+/-}$nor PlexinA $2^{+/-}$mice exhibit increases in sprouting axons (Fig. $7 D, E$; Table 1). Another measure of axon sprouting, the number of midline crossing CST axons is also significantly increased in $\mathrm{NgR}^{+/-}$PlexinA2 $2^{+/-}$mice relative to WT animals, but not in $\mathrm{NgR1}^{+/-}$or PlexinA2 ${ }^{+/-}$samples (Fig. 7 D, F; Table 1). Thus, a genetic interaction between $\mathrm{NgR} 1$ and PlexinA2 limits injury-induced axon growth in vivo.
Enhanced behavioral recovery in double-heterozygous $\mathrm{NgR1}^{+/-}$PlexinA2 ${ }^{+/-}$mice after PyX

The same PyX cohort was evaluated behaviorally for neurological function by counting missed steps in a grid walk. At $2 \mathrm{dpl}$, all groups show comparable impairment with a 50\% level of missed steps for the right forelimb and hindlimb. By $28 \mathrm{dpl}$ there is greater recovery in $\mathrm{NgR}^{+/-}$PlexinA2 $2^{+/-}$mice compared with WT $(p=0.003$, one-way ANOVA with Tukey multiplecomparisons test), whereas $\mathrm{NgR}^{+/-}$and PlexinA2 ${ }^{+/-}$animals show no significant difference from WT (Fig. $8 A$ ). In comparisons between all genotypes, only the double-heterozygous versus WT pair shows a statistically significant difference (Table 1). These deficits are specific to the lesion side because the intact side left limb errors are between 10 and $38 \%$ missed steps at $2 \mathrm{dpl}$ and between 8 and 33\% at $28 \mathrm{dpl}$ in all genotype groups (Fig. $9 A-C$ ). No significant functional recovery of the affected right-side limbs between 2 and $28 \mathrm{dpl}$ is observed in WT animals $(p=0.184$, paired $t$ test). In contrast, the other three genotypes exhibit improvement $\left(\mathrm{NgR}^{+/-} ; p=0.0165\right.$, PlexinA2 ${ }^{+/-} ; p=0.0477$, $\mathrm{NgR}^{+/-}$PlexinA2 ${ }^{+/-} ; p=0.004$, paired $t$ test; Fig. 8 B, C). After Bonferroni correction for four genotypes, only the double- 
heterozygous improvement remains significant (Table 1). Together, the data demonstrate a functional interaction of $\mathrm{NgR} 1$ and PlexinA2 to limit behavioral recovery after unilateral PyX injury.

\section{Discussion}

The major findings of the present study are the ability of Nogo-A to drive physical association of NgR1, PlexinA2, and CRMP2 in a signaling complex. Expression of these three proteins allows nonneuronal cells to respond morphologically to the presence of Nogo-A ligands. Cortical neurons require both $\mathrm{NgR} 1$ and PlexinA2 for Nogo-A inhibition of axonal regeneration. Moreover, genes for the two proteins interact, such that the doubleheterozygote state but not single-allele loss abrogates Nogo-A cellular action. In mice, unilateral corticospinal tract interruption at the medulla is followed by greater regenerative sprouting and neurological recovery when one allele of both $\mathrm{NgR} 1$ and PlexinA2 is deleted. Together, these data define a signal transduction pathway limiting axonal growth after adult mammalian CNS injury in which Nogo-A binding to NgR1 recruits transmembrane PlexinA2 and intracellular CRMP2.

The double-heterozygous phenotype in vitro and in vivo is indistinguishable from the single null for either $N g R 1$ or PlexinA2. Neither single-heterozygous cultured neurons nor single-heterozygous mice showed a significant difference from WT. There was a nonsignificant trend toward greater recovery of grid walking for the single-heterozygous mice. Increasing the statistical power with a larger $n$ value might reveal a weak effect of haploinsufficiency for Ngr1 and PlexinA2 in neurological recovery from PyX lesion.

A key aspect to uncovering this ternary signaling complex was the analysis of ligand-induced protein associations in primary neurons. The role of Plexin/CRMP downstream of Nogo-A/ $\mathrm{NgR} 1$ parallels their role downstream of Sema3/neuropilin during developmental axon repulsion (Deo et al., 2004; Schmidt and Strittmatter, 2007; Schmidt et al., 2008). The fact that Plexin receptors are auto-inhibited in the basal state may explain their diverse activation by a range of cues, including Semaphorins directly, neuropilin and NgR1 (Takahashi and Strittmatter, 2001; Janssen et al., 2012; Kong et al., 2016). Once intramolecular basal auto-inhibition is interrupted, then downstream activation recruiting CRMPs can proceed.

The CRMP1-5 family of proteins form heterotetramers and CRMP2 is the most prevalent family member (Goshima et al., 1995; Wang and Strittmatter, 1996, 1997; Deo et al., 2004; Schmidt and Strittmatter, 2007). The CRMP family titrates axonal growth in multiple situations (Goshima et al., 1995; Arimura et al., 2005; Niisato et al., 2012, 2013; Khazaei et al., 2014; Nagai et al., 2015, 2016; Takaya et al., 2017). Previous studies have suggested an involvement of CRMPs in myelin ligand signaling. In mouse experimental allergic encephalomyelitis, axonal degeneration requires both NgR1 and CRMP2 phosphorylation (Petratos et al., 2012). In addition, CRMP participates in MAG-induced axon growth inhibition and Rho activation in vitro (Mimura et al., 2006). CRMP has also been linked with RhoA as a substrate of RhoA/ROCK2, which is known to be downstream of NgR1 (Arimura et al., 2005; Petratos et al., 2012). However, coupling of NgR1 with CRMPs has previously been thought to be indirect without physical association. Our data document participation of CRMPs in a NgR1/Plexin signaling complex. Specific CRMP isoforms form hetero-oligomers with other CRMPs, and to a greater extent than homotetramers (Wang and Strittmatter, 1997; Deo et al., 2004). Therefore, CRMP2 involvement implies likely partic- ipation of other CRMP family members as well. CRMP4 was detected here in ligand stimulated NgR1 complexes and is a potential contributor to NgR1 signaling in vivo.

PlexinA2 is well known to participate in Semaphorin axon repulsion during development, both as a partner with Sema3binding neuropilins (Takahashi et al., 1999) and also as a direct Sema6 receptor (Renaud et al., 2008; Rünker et al., 2008; Shim et al., 2012). In addition, we had previously demonstrated a role for PlexinA2 in limiting corticospinal axon regenerative sprouting after adult mouse pyramidotomy (Shim et al., 2012). However, the ligand responsible for the PlexinA2 injury response phenotype was not defined. Sema6 expression by oligodendrocytes suggested one potential ligand (Shim et al., 2012). Here, we show physical coupling with NgR1 and a requirement for PlexinA2 in Nogo-A mediated axon growth inhibition. It is likely that interruption of Nogo-A/NgR1 signaling underlies the neural repair and recovery phenotype of PlexinA $2^{-/-}$mice after PyX.

Previous work has implicated p75NTR, Troy, and Lingol as coreceptors in NgR1 signaling (Wang et al., 2002a; Mi et al., 2004; Park et al., 2005; Shao et al., 2005). Here, we find that PlexinA2 is required for cortical neuron inhibition by Nogo-A in vitro and for corticospinal regenerative sprouting in vivo. The $\mathrm{NgR} 1 / \mathrm{Plexin} \mathrm{A} 2$ complex is also sufficient to mediate morphological responses in non-neuronal cells. It is possible that cortical projection neurons respond to Nogo-A via the NgR1/PlexinA2/CRMP pathway, while other neurons use different pathways. This might explain the limited in vivo regenerative phenotype focused on descending spinal projection axons observed for p75NTR, Troy and Lingol despite in vitro evidence for a role in DRG and cerebellar projection neurons. PlexinA2 expression is substantially greater in adult cerebral cortex than in cerebellum (Shim et al., 2012).

The utilization of PlexinA2 and CRMP2 for signal transduction by Nogo-A/NgR1 complexes documents shared mechanisms in axon growth inhibition during development and in the injured adult. Although the ligands and consequences are unique in these diverse situations, the inhibitory signaling pathways share downstream molecular components. Further studies of developmental axon guidance mechanisms in the injured CNS may accelerate progress toward overcoming barriers to neural repair.

\section{References}

Akbik FV, Bhagat SM, Patel PR, Cafferty WB, Strittmatter SM (2013) Anatomical plasticity of adult brain is titrated by nogo receptor 1 . Neuron 77:859-866.

Arimura N, Ménager C, Kawano Y, Yoshimura T, Kawabata S, Hattori A, Fukata Y, Amano M, Goshima Y, Inagaki M, Morone N, Usukura J, Kaibuchi K (2005) Phosphorylation by rho kinase regulates CRMP-2 activity in growth cones. Mol Cell Biol 25:9973-9984.

Atwal JK, Pinkston-Gosse J, Syken J, Stawicki S, Wu Y, Shatz C, TessierLavigne M (2008) PirB is a functional receptor for myelin inhibitors of axonal regeneration. Science 322:967-970.

Bhagat SM, Butler SS, Taylor JR, McEwen BS, Strittmatter SM (2016) Erasure of fear memories is prevented by nogo receptor 1 in adulthood. Mol Psychiatry 21:1281-1289.

Bradbury EJ, Moon LD, Popat RJ, King VR, Bennett GS, Patel PN, Fawcett JW, McMahon SB (2002) Chondroitinase ABC promotes functional recovery after spinal cord injury. Nature 416:636-640.

Budel S, Padukkavidana T, Liu BP, Feng Z, Hu F, Johnson S, Lauren J, Park JH, McGee AW, Liao J, Stillman A, Kim JE, Yang BZ, Sodi S, Gelernter J, Zhao H, Hisama F, Arnsten AF, Strittmatter SM (2008) Genetic variants of nogo-66 receptor with possible association to schizophrenia block myelin inhibition of axon growth. J Neurosci 28:13161-13172.

Cafferty WB, Strittmatter SM (2006) The nogo-nogo receptor pathway limits a spectrum of adult CNS axonal growth. J Neurosci 26:12242-12250.

Chen MS, Huber AB, van der Haar ME, Frank M, Schnell L, Spillmann AA, Christ F, Schwab ME (2000) Nogo-A is a myelin-associated neurite out- 
growth inhibitor and an antigen for monoclonal antibody IN-1. Nature 403:434-439.

Dell'Anno MT, Strittmatter SM (2017) Rewiring the spinal cord: direct and indirect strategies. Neurosci Lett 652:25-34.

Deo RC, Schmidt EF, Elhabazi A, Togashi H, Burley SK, Strittmatter SM (2004) Structural bases for CRMP function in plexin-dependent semaphorin3A signaling. EMBO J 23:9-22.

Duffy P, Schmandke A, Schmandke A, Sigworth J, Narumiya S, Cafferty WB, Strittmatter SM (2009) Rho-associated kinase II (ROCKII) limits axonal growth after trauma within the adult mouse spinal cord. J Neurosci 29:15266-15276.

Fawcett JW (2015) The extracellular matrix in plasticity and regeneration after CNS injury and neurodegenerative disease. Prog Brain Res 218:213-226.

Fink KL, Strittmatter SM, Cafferty WB (2015) Comprehensive corticospinal labeling with mu-crystallin transgene reveals axon regeneration after spinal cord trauma in ngr ${ }^{-1-}$ mice. J Neurosci 35:15403-15418.

Fournier AE, GrandPre T, Strittmatter SM (2001) Identification of a receptor mediating nogo-66 inhibition of axonal regeneration. Nature 409:341-346.

Fournier AE, Takizawa BT, Strittmatter SM (2003) Rho kinase inhibition enhances axonal regeneration in the injured CNS. J Neurosci 23:14161423.

Goshima Y, Nakamura F, Strittmatter P, Strittmatter SM (1995) Collapsininduced growth cone collapse mediated by an intracellular protein related to UNC-33. Nature 376:509-514.

GrandPré T, Nakamura F, Vartanian T, Strittmatter SM (2000) Identification of the nogo inhibitor of axon regeneration as a reticulon protein. Nature 403:439-444.

GrandPré T, Li S, Strittmatter SM (2002) Nogo-66 receptor antagonist peptide promotes axonal regeneration. Nature 417:547-551.

Harel NY, Strittmatter SM (2006) Can regenerating axons recapitulate developmental guidance during recovery from spinal cord injury? Nat Rev Neurosci 7:603-616.

Huebner EA, Kim BG, Duffy PJ, Brown RH, Strittmatter SM (2011) A multi-domain fragment of nogo-A protein is a potent inhibitor of cortical axon regeneration via nogo receptor 1. J Biol Chem 286:18026-18036.

Janssen BJ, Malinauskas T, Weir GA, Cader MZ, Siebold C, Jones EY (2012) Neuropilins lock secreted semaphorins onto plexins in a ternary signaling complex. Nat Struct Mol Biol 19:1293-1299.

Ji B, Li M, Wu WT, Yick LW, Lee X, Shao Z, Wang J, So KF, McCoy JM, Pepinsky RB, Mi S, Relton JK (2006) LINGO-1 antagonist promotes functional recovery and axonal sprouting after spinal cord injury. Mol Cell Neurosci 33:311-320.

Jin Z, Strittmatter SM (1997) Racl mediates collapsin-1-induced growth cone collapse. J Neurosci 17:6256-6263.

Khazaei MR, Girouard MP, Alchini R, Ong Tone S, Shimada T, Bechstedt S, Cowan M, Guillet D, Wiseman PW, Brouhard G, Cloutier JF, Fournier AE (2014) Collapsin response mediator protein 4 regulates growth cone dynamics through the actin and microtubule cytoskeleton. J Biol Chem 289:30133-30143

Kim JE, Liu BP, Park JH, Strittmatter SM (2004) Nogo-66 receptor prevents raphespinal and rubrospinal axon regeneration and limits functional recovery from spinal cord injury. Neuron 44:439-451.

Kong Y, Janssen BJ, Malinauskas T, Vangoor VR, Coles CH, Kaufmann R, Ni T, Gilbert RJ, Padilla-Parra S, Pasterkamp RJ, Jones EY (2016) Structural basis for plexin activation and regulation. Neuron 91:548-560.

Kottis V, Thibault P, Mikol D, Xiao ZC, Zhang R, Dergham P, Braun PE (2002) Oligodendrocyte-myelin glycoprotein (OMgp) is an inhibitor of neurite outgrowth. J Neurochem 82:1566-1569.

Laurén J, Hu F, Chin J, Liao J, Airaksinen MS, Strittmatter SM (2007) Characterization of myelin ligand complexes with neuronal nogo-66 receptor family members. J Biol Chem 282:5715-5725.

Lee JK, Kim JE, Sivula M, Strittmatter SM (2004) Nogo receptor antagonism promotes stroke recovery by enhancing axonal plasticity. J Neurosci 24:6209-6217.

Li S, Liu BP, Budel S, Li M, Ji B, Walus L, Li W, Jirik A, Rabacchi S, Choi E, Worley D, Sah DW, Pepinsky B, Lee D, Relton J, Strittmatter SM (2004) Blockade of nogo-66, myelin-associated glycoprotein, and oligodendrocyte myelin glycoprotein by soluble nogo-66 receptor promotes axonal sprouting and recovery after spinal injury. J Neurosci 24:10511-10520.

Liu BP, Fournier A, GrandPré T, Strittmatter SM (2002) Myelin-associated glycoprotein as a functional ligand for the nogo-66 receptor. Science 297:1190-1193.

Liu BP, Cafferty WB, Budel SO, Strittmatter SM (2006) Extracellular regulators of axonal growth in the adult central nervous system. Philos Trans R Soc Lond B Biol Sci 361:1593-1610.

Liu K, Tedeschi A, Park KK, He Z (2011) Neuronal intrinsic mechanisms of axon regeneration. Annu Rev Neurosci 34:131-152.

McGee AW, Yang Y, Fischer QS, Daw NW, Strittmatter SM (2005) Experience-driven plasticity of visual cortex limited by myelin and nogo receptor. Science 309:2222-2226.

McKerracher L, David S, Jackson DL, Kottis V, Dunn RJ, Braun PE (1994) Identification of myelin-associated glycoprotein as a major myelinderived inhibitor of neurite growth. Neuron 13:805-811.

Mi S, Lee X, Shao Z, Thill G, Ji B, Relton J, Levesque M, Allaire N, Perrin S, Sands B, Crowell T, Cate RL, McCoy JM, Pepinsky RB (2004) LINGO-1 is a component of the nogo-66 receptor/p75 signaling complex. Nat Neurosci 7:221-228.

Mi S, Miller RH, Lee X, Scott ML, Shulag-Morskaya S, Shao Z, Chang J, Thill G, Levesque M, Zhang M, Hession C, Sah D, Trapp B, He Z, Jung V, McCoy JM, Pepinsky RB (2005) LINGO-1 negatively regulates myelination by oligodendrocytes. Nat Neurosci 8:745-751.

Mi S, Hu B, Hahm K, Luo Y, Kam Hui ES, Yuan Q, Wong WM, Wang L, Su H, Chu TH, Guo J, Zhang W, So KF, Pepinsky B, Shao Z, Graff C, Garber E, Jung $\mathrm{V}, \mathrm{Wu} \mathrm{EX}, \mathrm{Wu} \mathrm{W}$ (2007) LINGO-1 antagonist promotes spinal cord remyelination and axonal integrity in MOG-induced experimental autoimmune encephalomyelitis. Nat Med 13:1228-1233.

Mimura F, Yamagishi S, Arimura N, Fujitani M, Kubo T, Kaibuchi K, Yamashita T (2006) Myelin-associated glycoprotein inhibits microtubule assembly by a rho-kinase-dependent mechanism. J Biol Chem 281: 15970-15979.

Mukhopadhyay G, Doherty P, Walsh FS, Crocker PR, Filbin MT (1994) A novel role for myelin-associated glycoprotein as an inhibitor of axonal regeneration. Neuron 13:757-767.

Nagai J, Kitamura Y, Owada K, Yamashita N, Takei K, Goshima Y, Ohshima $\mathrm{T}$ (2015) Crmp4 deletion promotes recovery from spinal cord injury by neuroprotection and limited scar formation. Sci Rep 5:8269.

Nagai J, Takaya R, Piao W, Goshima Y, Ohshima T (2016) Deletion of Crmp4 attenuates CSPG-induced inhibition of axonal growth and induces nociceptive recovery after spinal cord injury. Mol Cell Neurosci 74:42-48.

Nakamura F, Tanaka M, Takahashi T, Kalb RG, Strittmatter SM (1998) Neuropilin-1 extracellular domains mediate semaphorin D/III-induced growth cone collapse. Neuron 21:1093-1100.

Niisato E, Nagai J, Yamashita N, Abe T, Kiyonari H, Goshima Y, Ohshima T (2012) CRMP4 suppresses apical dendrite bifurcation of CA1 pyramidal neurons in the mouse hippocampus. Dev Neurobiol 72:1447-1457.

Niisato E, Nagai J, Yamashita N, Nakamura F, Goshima Y, Ohshima T (2013) Phosphorylation of CRMP2 is involved in proper bifurcation of the apical dendrite of hippocampal CA1 pyramidal neurons. Dev Neurobiol 73: 142-151.

Park JB, Yiu G, Kaneko S, Wang J, Chang J, He XL, Garcia KC, He Z (2005) A TNF receptor family member, TROY, is a coreceptor with Nogo receptor in mediating the inhibitory activity of myelin inhibitors. Neuron 45 : 345-351.

Patel A, Li Z, Canete P, Strobl H, Dulin J, Kadoya K, Gibbs D, Poplawski GHD (2018) AxonTracer: a novel ImageJ plugin for automated quantification of axon regeneration in spinal cord tissue. BMC Neurosci 19:8.

Petratos S, Ozturk E, Azari MF, Kenny R, Lee JY, Magee KA, Harvey AR, McDonald C, Taghian K, Moussa L, Mun Aui P, Siatskas C, Litwak S, Fehlings MG, Strittmatter SM, Bernard CC (2012) Limiting multiple sclerosis related axonopathy by blocking nogo receptor and CRMP-2 phosphorylation. Brain 135:1794-1818.

Renaud J, Kerjan G, Sumita I, Zagar Y, Georget V, Kim D, Fouquet C, Suda K, Sanbo M, Suto F, Ackerman SL, Mitchell KJ, Fujisawa H, Chédotal A (2008) Plexin-A2 and its ligand, Sema6A, control nucleus-centrosome coupling in migrating granule cells. Nat Neurosci 11:440-449.

Rünker AE, Little GE, Suto F, Fujisawa H, Mitchell KJ (2008) Semaphorin-6A controls guidance of corticospinal tract axons at multiple choice points. Neural Dev 3:34.

Schmidt EF, Strittmatter SM (2007) The CRMP family of proteins and their role in Sema3A signaling. Adv Exp Med Biol 600:1-11.

Schmidt EF, Shim SO, Strittmatter SM (2008) Release of MICAL autoinhi- 
bition by semaphorin-plexin signaling promotes interaction with collapsin response mediator protein. J Neurosci 28:2287-2297.

Sekine Y, Siegel CS, Sekine-Konno T, Cafferty WBJ, Strittmatter SM (2018a) The nociceptin receptor inhibits axonal regeneration and recovery from spinal cord injury. Sci Signal 11:eaao4180.

Sekine Y, Lin-Moore A, Chenette DM, Wang X, Jiang Z, Cafferty WB, Hammarlund M, Strittmatter SM (2018b) Functional genome-wide screen identifies pathways restricting central nervous system axonal regeneration. Cell Rep 23:415-428.

Shao Z, Browning JL, Lee X, Scott ML, Shulga-Morskaya S, Allaire N, Thill G, Levesque M, Sah D, McCoy JM, Murray B, Jung V, Pepinsky RB, Mi S (2005) TAJ/TROY, an orphan TNF receptor family member, binds nogo-66 receptor 1 and regulates axonal regeneration. Neuron 45:353-359.

Shim SO, Cafferty WB, Schmidt EC, Kim BG, Fujisawa H, Strittmatter SM (2012) PlexinA2 limits recovery from corticospinal axotomy by mediating oligodendrocyte-derived Sema6A growth inhibition. Mol Cell Neurosci 50:193-200.

Snow DM, Lemmon V, Carrino DA, Caplan AI, Silver J (1990) Sulfated proteoglycans in astroglial barriers inhibit neurite outgrowth in vitro. Exp Neurol 109:111-130.

Song XY, Zhong JH, Wang X, Zhou XF (2004) Suppression of p75NTR does not promote regeneration of injured spinal cord in mice. J Neurosci 24:542-546.

Starkey ML, Barritt AW, Yip PK, Davies M, Hamers FP, McMahon SB, Bradbury EJ (2005) Assessing behavioural function following a pyramidotomy lesion of the corticospinal tract in adult mice. Exp Neurol 195:524-539.

Suto F, Murakami Y, Nakamura F, Goshima Y, Fujisawa H (2003) Identification and characterization of a novel mouse plexin, plexin-A4. Mech Dev 120:385-396.

Takahashi T, Strittmatter SM (2001) Plexinal autoinhibition by the plexin sema domain. Neuron 29:429-439.
Takahashi T, Fournier A, Nakamura F, Wang LH, Murakami Y, Kalb RG, Fujisawa H, Strittmatter SM (1999) Plexin-neuropilin-1 complexes form functional semaphorin-3A receptors. Cell 99:59-69.

Takaya R, Nagai J, Piao W, Niisato E, Nakabayashi T, Yamazaki Y, Nakamura F, Yamashita N, Kolattukudy P, Goshima Y, Ohshima T (2017) CRMP1 and CRMP4 are required for proper orientation of dendrites of cerebral pyramidal neurons in the developing mouse brain. Brain Res 1655:161-167.

Tessier-Lavigne M, Goodman CS (1996) The molecular biology of axon guidance. Science 274:1123-1133.

Wang KC, Kim JA, Sivasankaran R, Segal R, He Z (2002a) P75 interacts with the Nogo receptor as a co-receptor for Nogo, MAG and OMgp. Nature 420:74-78

Wang KC, Koprivica V, Kim JA, Sivasankaran R, Guo Y, Neve RL, He Z (2002b) Oligodendrocyte-myelin glycoprotein is a nogo receptor ligand that inhibits neurite outgrowth. Nature 417:941-944.

Wang LH, Strittmatter SM (1996) A family of rat CRMP genes is differentially expressed in the nervous system. J Neurosci 16:6197-6207.

Wang LH, Strittmatter SM (1997) Brain CRMP forms heterotetramers similar to liver dihydropyrimidinase. J Neurochem 69:2261-2269.

Wang X, Baughman KW, Basso DM, Strittmatter SM (2006) Delayed nogo receptor therapy improves recovery from spinal cord contusion. Ann Neurol 60:540-549.

Wang X, Duffy P, McGee AW, Hasan O, Gould G, Tu N, Harel NY, Huang Y, Carson RE, Weinzimmer D, Ropchan J, Benowitz LI, Cafferty WB, Strittmatter SM (2011) Recovery from chronic spinal cord contusion after nogo receptor intervention. Ann Neurol 70:805-821.

Wang X, Yigitkanli K, Kim CY, Sekine-Komo T, Wirak D, Frieden E, Bhargava A, Maynard G, Cafferty WB, Strittmatter SM (2014) Human $\mathrm{NgR}-\mathrm{fc}$ decoy protein via lumbar intrathecal bolus administration enhances recovery from rat spinal cord contusion. J Neurotrauma 31:19551966. 